\title{
HYPERSPECTRAL REMOTE SENSING: EVALUATION OF R95/HSS SENSOR FOR SPATIALIZATION AND CHARACTERIZATION OF SOIL IN MANAUS, AM - BRAZIL
}

\author{
Manoel Ricardo Dourado Correia ${ }^{1}$ and Rutenio Luiz Castro de Araújo²
}

Recebido em 15 junho, 2010 / Aceito em 7 maio, 2012

Received on June 15, 2010 / Accepted on May 7, 2012

\begin{abstract}
The HSS (Hyperspectral Scanner System) was evaluated for characterization and spatialization of soils in Manaus, AM, Brazil, with 3 meter resolution images. The images (37 bands between 0,43 and 2,37 $\mu \mathrm{m}$ ) were converted from radiance values to surface reflectance using the Fast Line-of-sight Atmospheric Analysis of Spectral Hypercubes (FLAASH) applicative, based on the MODTRAN +4 (Moderate Resolution Transmittance) a radioactive transfer model. Preceding collection of soil samples, the main soil classes were identified through the SAM (Spectral Angle Mapper) method in order to facilitate analysis of the spectral characteristics of the studied area. Finally, for 13 samples, correlations among soil characteristics and spectral data from the HSS sensor, and spectral curves obtained in laboratory were carried out. Results indicated that: (a) the atmospheric correction accomplished with the FLAASH applicative was appropriate, despite difficulties for total removal of the water vapor feature at $0.94 \mu \mathrm{m}$ and at short-wave infrared band, near to $2.0 \mu \mathrm{m}$. In general, a spectral coherence of the HSS sensor was confirmed with the information found in literature and the spectrum obtained in the laboratory; (b) a good capacity for spectral identification was observed with the SAM classifier as the results provided an appropriate soil preidentification, helping as well to define sites for field work; (c) the spectral curves representative of the soil classes are comparable both for laboratory and sensor data. Usually, correlations between both data acquisition environments (laboratory and HSS) are high.
\end{abstract}

Keywords: Hyperspectral Remote Sensing, R95/HSS sensor, spectrometry of soils, spatialization and characterization of soil types, spectral indices.

RESUMO. Avaliou-se o sensor HSS (Hyperspectral Scanner System) para a caracterização e espacialização de solos na cidade de Manaus, AM, Brazil, com imagens de 3 metros de resolução espacial. As imagens (37 bandas entre 0,43-2,37 $\mu \mathrm{m}$ ) foram convertidas de valores de radiância para reflectância de superfície, usando um aplicativo (FLAASH) Fast Line-of-sight Atmospheric Analysis of Spectral Hypercubes baseado no modelo de transferência radiativa MODTRAN+4 (Moderate Resolution Transmittance). Para facilitar a análise das características espectrais da área de estudo e da discriminação dos principais tipos de solos presentes, foram pré-identificadas as classes de solos através do método SAM (Spectral Angle Mapper)antes da coleta das amostras de solo em campo. Por fim, as correlações entre características dos solos e dados espectrais do sensor (HSS) e curvas espectrais de laboratório foram realizadas em 13 amostras. Os resultados obtidos indicaram que: (a) a correção atmosférica realizada com o aplicativo FLAASH foi apropriada, apesar das dificuldades de plena remoção da feição de vapor d'água em 0,94 $\mu \mathrm{m}$ e na faixa do infravermelho de ondas curtas, próximo de 2,0 $\mathrm{mm}$. No geral, constatou-se coerência dos espectros do sensor HSS com as informações da literatura e dos espectros obtidos em laboratório; (b) foi observada boa capacidade de identificação espectral com o classificador SAM cujos resultados possibilitaram a pré-identificação adequada das classes de solos, bem como ajudaram a definir as áreas onde foram coletadas as amostras de campo; (c) As curvas espectrais representativas das classes de solo para os dados de laboratório e do sensor (HSS) são correlacionáveis. As correlações entre os dois ambientes de aquisição de dados (laboratório e HSS) são normalmente altas.

Palavras-chave: Sensoriamento Remoto Hiperespectral, sensor R95/HSS, espectrometria de solos, espacialização e caracterização de solos, índices espectrais.

\footnotetext{
${ }^{1}$ Centro Universitário do Norte (UNINORTE/LAUREATE), Rua Dez de Julho, 873, Centro, 69010-060 Manaus, AM, Brazil. Phone: +55(92) 3212-5000

-E-mail: manoelricardogeo@gmail.com

2Departamento de Geociências, Universidade Federal do Amazonas, Av. General Rodrigo Otávio Jordão Ramos, 3000, Setor Norte, Bloco 7, Campus Universitário, Coroado, 69077-000 Manaus, AM, Brazil. Phone: +55(92) 3305-2862 - E-mail: ruie@ufam.edu.br
} 


\section{INTRODUCTION}

When the topic is the development of an area, the soil has a high degree of relevance among the existing natural resources, because from it derive several products to feed the population, showing also the evidences of underground minerals.

Remote sensing is an important tool in studies related to agriculture and, particularly, for soil characterization and spatialization. Currently, the soil monitoring is a great challenge, since soils exhibit a continuous time and space variation. Such monitoring can help in a more effective way the preparation of pedologic maps, use of the soil, agricultural aptitude, and in a better use of the relationships of the soil potential for food production.

Presently, the studies connected with remote sensing undergo paradigm changes with the development of imaging spectroscopy and the hyperspectral sensor systems: while the principle for analysis of data obtained by the multispectral sensor is based on search for target identification, in other words, if it is vegetation, exposed soil, outcrop etc.; when managing data from the hyperspectral sensor, the concern, among others, is about the health and vigor of the vegetation, the mineralogical composition of the exposed soil and rock outcrops (Baptista, 2006).

In the Brazilian territory, mainly in its northern portion, few and restricted collections of optical hyperspectral data with a scientific purpose were carried out. With the intention of filling in this gap in the scientific community, the Sistema de Proteção da Amazônia - SIPAM (System for the Amazonian Protection), acquired a HSS sensor, set up in a R-95 Bandeirante aircraft and it has 50 channels that continuously cover the area from the visible to thermal infrared, in the region between 0.4 to $12.6 \mu \mathrm{m}$. These channels have 12 quantizing bits (4096 Digital Levels) and approximately 2.5 meters of spatial resolution (Moreira et al., 2005).

The HSS/SIPAM sensor has the capacity to acquire images in a great number of narrow and contiguous spectral bands and make possible the extraction of reflectance spectra from each pixel of an image; in other words, for each pixel of the scene, a spectrum with a practically continuous form can be acquired, producing data with spectral resolution that is enough to identify materials through their absorption features. These spectra are so detailed that they can be directly compared with spectral curves similar to those found in the field or laboratory conditions.

Analysis of the reflectance spectra of the different soils found in the imaged scene will be possible with data obtained through this hyperspectral scanner system. In those spectra absorption spectral features of the main mineral components of the soils are found.
The importance of characterizing and classifying soils through remote sensors is due to the need of obtaining a wide vision of the area under study. It also facilitates the survey and follow up of the use of the soil in areas where access is difficult. Surveying costs are reduced, mainly in tropical areas that demand more logistics effort.

The objective of this research is to evaluate the potential of the HSS data for the spatiatization and spectral characterization of pedologic features in a part of the northwestern and southeastern portions of the city of Manaus, State of Amazonas, Brazil.

\section{CHARACTERIZATION OF THE AREAS UNDER STUDY}

The studied areas are in the metropolitan area of the city of Manaus (AM), specifically, in two places, comprised by two scenes of the HSS sensor (Fig. 1). Scene 1 is represented in blue, situated in the northwestern portion, near to Avenida do Turismo and Sistema de Proteção da Amazônia - SIPAM (System for the Amazonian Protection), having as the main reference, the international airport Eduardo Gomes. Scene 2 is represented in red, situated in the southeastern portion, near to BR-319 (interstate road).

The Manaus area is in the Amazon Paleozoic Basin's geological context, located between the Guyana Shield to the north, and Brasil Central Shield to the south. The regional substratum is composed of the following geologic units: Alluvium (Cenozoic), Alter do Chão (Mesozoic), Trombetas (Paleozoic) and Prosperança (Paleozoic).

In this municipal district area, laterites have a wide distribution and good representability, and although they do not represent a formal lithostratigraphic unit, they are of great importance for understanding the Cenozoic geology, because they are excellent stratigraphic markers (Fernandes Filho et al., 1997). The occurrence of laterites with an argillaceous composition is observed covering a great part of the studied area, specifically in Scene 1.

The pedologic units of Manaus, updated from data issued by the Brazilian System of Soil Classification (EMBRAPA, 2006), predominantly are: Latosols, Argisols, Spodosols, Gleysols and Neosols. According to Leal (1996), in the Manaus area, Latosols prevail over Spodosols.

The studied area is characterized by annual air temperature above $26^{\circ} \mathrm{C}$. The lower average temperatures are registered in February and March, something around $25.8^{\circ} \mathrm{C}$, and it can reach figures slightly below $25.0^{\circ} \mathrm{C}$. The highest temperatures were observed from August to October, with averages from $27.4^{\circ} \mathrm{C}$ to $27.9^{\circ} \mathrm{C}$, respectively; and the maximum averages may reach $28.8^{\circ} \mathrm{C}$ and $30.2^{\circ} \mathrm{C}$, respectively (adapted from Oliveira et al., 2008). 

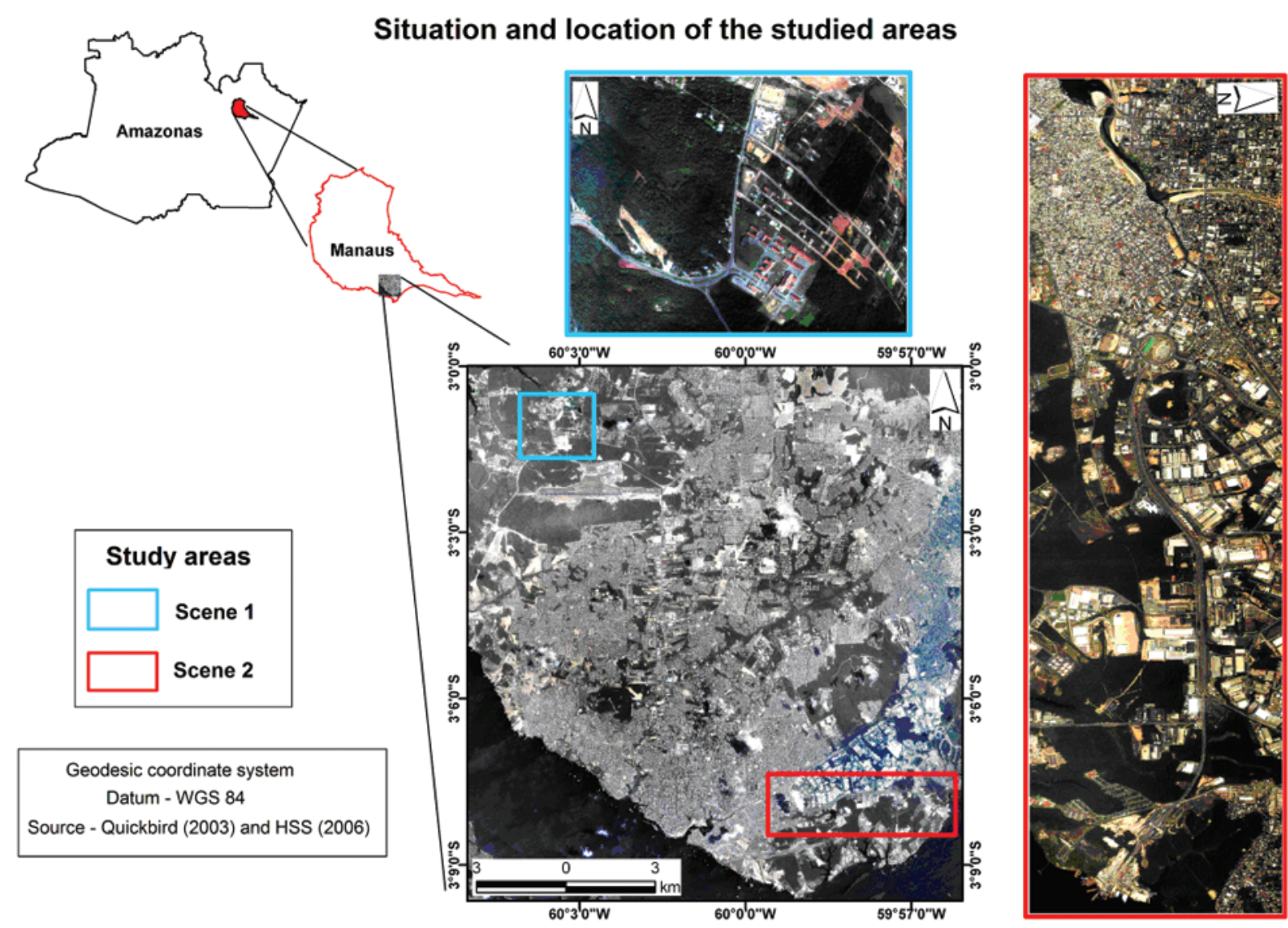

Figure 1 - Situation and location of the studied areas.

\section{METHODOLOGICAL PROCEDURES}

\section{HSS Image acquisition and processing}

Two scenes were used for the accomplishment of the soil spectral study, with 37 bands, within the spectral interval from 0.43 to $2.37 \mu \mathrm{m}$, which were radiometricly processed and atmospherically corrected before the preidentification of the soil classes in the images and, later, selection of the sampling sites in the field.

Scene 1 (Fig. 1) was obtained on December 16, 2007, at 00:58:00 p.m. GMT (-3 hours, local time, in the central point of the Scene). Scene 2 (Fig. 1) was obtained on June 06, 2007, at 03:23:00 p.m. GMT ( -3 hours, local time, in the central point of the Scene). Both HSS images were acquired with the IFOV of $2.5 \mathrm{mrad}$, at a flight height of approximately $1192 \mathrm{~m}$ above the ground, resulting in an average GIFOV (Ground Instantaneous Field of View) of $3 \mathrm{~m}$ along the imaged band.

The radiance images in $\mu \mathrm{W} . \mathrm{cm}^{-2} . \mathrm{sr}^{-1} . \mathrm{nm}^{-1}$ used in this work were obtained using the processing applicative "AHS Import Utility Program" from the sensor's manufacturer. Using this applicative, the initial binary format was changed to BIL (Band Inter- leaved by Line) format. During processing the reflected spectrum bands or digital numbers were converted into radiance values (Reflective Calibration), as well as the auxiliary files recorded jointly to the image binary file, among them, the flight information and the required parameters for atmospheric correction.

For the atmospheric correction and reduction of the HSS radiance data for surface reflectance, the FLAASH (Research Systems, 2000) applicative was used. This applicative uses the MODTRAN+4 (Moderate Resolution Transmittance) code of radioactive transfer, correcting wavelengths in the visible, proximal infrared and shortwave infrared, up to $3 \mu \mathrm{m}$. The following imaging parameters were used in this applicative: the coordinate, ground elevation, flight height and time. The ground elevation at the referred Scene sites, 50 meters above the average sea level, were obtained in the digital elevation model from SRTM (Shuttle Radar Topography Mission), and other information were obtained with registers made by the sensor's GPS (Global Positioning System), all above mentioned parameters are available in the scenes' auxiliary files. 


\section{Preidentification of the soil classes at the scenes and selection of field sampling sites}

The classifier SAM - Spectral Angle Mapper, was used for preidentification of the soil classes at the scenes and selection of the field sampling sites. The objective of the analysis of this mapping is a preidentification of the different soil types at the scenes, and for both processing procedures reference spectra obtained with 5pixels average was used, visually selected at the scenes. Thirteen soil samples were collected, from the superficial layer (0 to $20 \mathrm{~cm}$ from the surface) and other different sites.

The SAM - Spectral Angle Mapper (Kruse et al., 1993) is a classifier that makes possible a fast mapping, using an algorithm that determines the spectral similarity among two or more spectra, calculating the angle between the spectra and associating it with vectors in a space with the same dimensions ( $n$-dimensional) of the number of bands.

\section{Obtaining the bidirectional reflectance factor (FRB) at the laboratory and physicochemical and mineralogical analyses (diffractometric)}

In order to obtain the bidirectional reflectance factor (FRB) at the laboratory and from the physicochemical and mineralogical analyses (diffractometric), the used samples were dried in a drying oven at $60^{\circ} \mathrm{C}$, for 48 hours. This was necessary to standardize the humidity condition. After preparation, the samples were conditioned in containers with $50 \mathrm{~cm}^{2}$ of area, forming a $5 \mathrm{~cm}$ thick soil layer, eliminating, in this way, possible interferences from the bottom of the container during the spectral radiance measurement.

The radiance measurements, for obtaining the soil radiometric data, were carried out at the Instituto de Estudos Avançados (IEAv), organization of the Aeronautics Command headquartered in São José dos Campos, State of São Paulo, at the Radiometry and Characterization of Optical Sensors Laboratory (LaRaC), using the ASD (Analytical Spectral Devices) FieldSpec ${ }^{\circledR}$ Pro spectroradiometer. Measurements were accomplished with temperature varying between 18 and $20^{\circ} \mathrm{C}$ and with relative humidity between 50 and $70 \%$. This equipment presents data at $1 \mathrm{~nm}$ intervals within the spectral range from 0.35 to $2.5 \mu \mathrm{m}$.

In order to accomplish the measurements, the spectroradiometer's sensor head, with a $25^{\circ}$ field of view (FOV), positioned in a vertical shot geometry, to nadir, at a height of approximately $4 \mathrm{~cm}$ from the target top, resulting in a sight projection with a diameter of approximately $3 \mathrm{~cm}$ on the sample. The ASD Pro-Lamp was the illuminator, consisting of a $50 \mathrm{~W}$ tungsten halogen lamp fed by a direct current source; which was fastened on a tripod, and positioned $25 \mathrm{~cm}$ distant from the sample in a oblique sight, with a $45^{\circ}$ zenital angle.
A Spectralon plate, model SRT-99-120, by Labsphere was used, its reflectance is near 100\%; according to the manufacturer's calibration certificate, it can be considered as an approximately Lambertian surface along the used wavelengths (Melo et al., 2009).

The ratio between the spectral radiance reflected by a soil sample surface and the spectral radiance reflected by the Spectralon reference plate, as shown in Eq. (1), under the same illumination and acquisition geometry conditions, gave the Spectral Bidirectional Reflectance Factor of the sample (FRBE sample).

$$
\operatorname{FBRE}_{\text {sample }}(\lambda) \frac{L_{\text {sample }}(\lambda)}{L_{\text {plate }}(\lambda)}
$$

where: $\operatorname{FBRE}_{\text {sample }}(\lambda)$ is the Spectral Bidirectional Reflectance Factor; $L_{\text {sample }}(\lambda)$ and $L_{\text {plate }}(\lambda)$ are the sample and the Spectralon plate's Radiance.

However, the absolute reflectance of a target Eq. (2), according to Moreira (2008), may be calculated multiplying the sample's bidirectional reflectance factor by the plate's reflectance factor, supplied by the manufacturer, obtaining:

$$
\mathrm{R}_{\text {sample }}(\lambda)=\operatorname{FBRE}_{\text {sample }}(\lambda) * \mathrm{C}_{\text {plate }}(\lambda)
$$

where: $R_{\text {sample }}(\lambda)$ is the sample's absolute reflectance; and $\mathrm{C}_{\text {plate }}(\lambda)$ is the reference plate's reflectance, supplied by the manufacturer.

\section{Correlation among the soil characteristics and spectral data of the (HSS/FRB) sensor and physicochemical analyses}

The correlation analysis was applied based on laboratory spectra (FRB) and the (HSS) image for 13 samples, in order to establish the relationship among spectral data and soil constituents. Firstly, the relationship of the soil physicochemical constituents were analyzed amongst themselves. Then, it was necessary that the laboratory data had the same spectral resolution of the HSS data, in other words, $0.03 \mu \mathrm{m}$, in order to reach higher precision when checking the similarity among the obtained spectra. It would be much more complicated to convolute the HSS data for the laboratory results, since the radiometric data have a much more refined resolution, of about $0.001 \mu \mathrm{m}$.

A spectra convolution procedure was undertaken, through the spectral resampling module of the ENVI ${ }^{\circledR}$ software. The spectral data were convoluted using the HSS sensor's response function, through an ASCII file, with information about width at half-height (FWHM). 
For each sample collected in the field, for the laboratory and HSS spectra, there were adopted bands from 0.43 to $1.0 \mu \mathrm{m}$ and 2.0 to $2.37 \mu \mathrm{m}$ for verifying the correlation between these two variables. Scatter diagrams were generated to describe these relationships. In these analyses the spectral band from $1.0 \mu \mathrm{m}$ to $2.0 \mu \mathrm{m}$ was disregarded for both sensors. For a given wavelength, the best curve adjustment in relation to the scatter diagrams was chosen following this criterion: the highest value of the linear correlation coefficient with the smallest standard error. In order to accomplish that, the spectral data were considered as following a normal distribution.

\section{RESULTS AND DISCUSSION}

\section{Obtaining the radiance and reflectance images}

The "AHS Import Utility Program" applicative offers possibilities for geometric corrections, such as: S-Bend Correction, V/H Correction, Thermal Calibration and Reflective Calibration. The improvements presented by these options were related with the image's visual aspect but none of the above options was used because the intention was to preserve the image's radiometry. It should be emphasized that in the preprocessing stages no geometric corrections were done, mainly the georeferrencing.

In this conversion stage from radiance to surface reflectance, the FLAASH module's modtran4+ algorithm, performs adjustments, mainly, at the oxygen (band 10), carbon dioxide (band 22 and band 23) and water vapor (band 14, band 18 and band 19) levels for each pixel of the image. As a result, this method eliminates the absorption bands caused by the above mentioned gases.

Several processing attempts were carried out with variations of the FLAASH parameters, in order to obtain a better atmospheric correction, due to the variability of the atmospheric concentration in the images, mainly as a result of the water vapor caused by the proximity of water bodies.

The same parameters described by Moreira (2008) were practically used for obtaining a better atmospheric correction. The main differences found were for correction of the water vapor, $\mathrm{CO}_{2}$ concentration and channel 19 non spectral deviation.

Moreira (2008) evaluated that water vapor absorption peak should happen in channel 18, corresponding to the $0.944 \mu \mathrm{m}$ band, however it was verified that the absorption peak happened in channel 19, whose position informed in the calibration was of $0.971 \mu \mathrm{m}$ and, therefore, it should be less susceptible to absorption by the atmospheric water vapor. The spectral deviation found by the referred author in the first 20 VNIR bands are on the order of $0.017 \mu \mathrm{m}$. According to Moreira (2008), the aspects related to maintenance of the sensor's optical set, carried out after the manufacturer's spectral calibration done in 2004, may have caused such spectral deviation.

The atmospheric correction, whose scenes' spectra that better adjusted to the field spectra, was obtained with the Tropical model of atmosphere and the Urban model of aerosols, without the use of the processing option with the K-T (Kauffman-Tanré) aerosol estimate, or the WR (Water Retrieval) estimate of water vapor. For the water vapor correction the option used was the WCM (Water Column Multiplier) with values from 0.45 to 60 . The initial visibility of $40 \mathrm{~km}$ was assumed for the scene visibility. Concentration of carbonic gas used is around 250 and 390 ppm (part per million) and, finally, the first 20 VNIR bands were not moved, as exposed by Moreira (2008).

Since a better curve smoothing and elimination of the small residual variations observed in the corrected image after being processed by FLAASH, mainly variations caused by the water vapor and $\mathrm{CO}_{2}$, was being sought, it became necessary an EFFORT spectral filtering, that presented better results with the use of a $3^{\text {rd }}$ order polynomial in the segment bound by bands 12 to 20 , the influence area of the $0.94 \mu \mathrm{m}$ water vapor, and other, of $2^{\text {nd }}$ order, in other segment, from channel 22 to 26 , area close to $2.05 \mu \mathrm{m}$, under the $\mathrm{CO}_{2}$ influence.

Upon definition of a better atmospheric correction, with their respective spectral filterings, the reflectance images were thoroughly explored with the purpose of evaluating the spectra of the scene's targets, including natural targets, whose characteristics were also used as parameters for qualitative analysis.

In general, coherence of the HSS spectra was verified both for information from literature and the spectra obtained at the laboratory. These spectra obtained from pixels - from exposed soil, water bodies and green vegetation - are targets of several portions of the scene that were used for qualitative analysis of the reflectance spectra (Fig. 2). These targets are presented with the real color corresponding composition: $\mathrm{R}$ (channel $7 ; 0.668 \mu \mathrm{m})$, $\mathrm{G}$ (channel 4; $0.54 \mu \mathrm{m}$ ), and $\mathrm{B}$ (channel $1 ; 0.627 \mu \mathrm{m}$ ).

\section{Preidentification of the soil classes in the images and selection of the field sampling sites}

During this stage, the identified soil classes facilitated the definition of the areas where field samples were collected. In order to identify the soil classes at the scenes and subsequent field samples collection, not only the basic elements for analysis and interpretation were used, those from which information about objects are draw out. Those elements are shade/color, texture, size, 

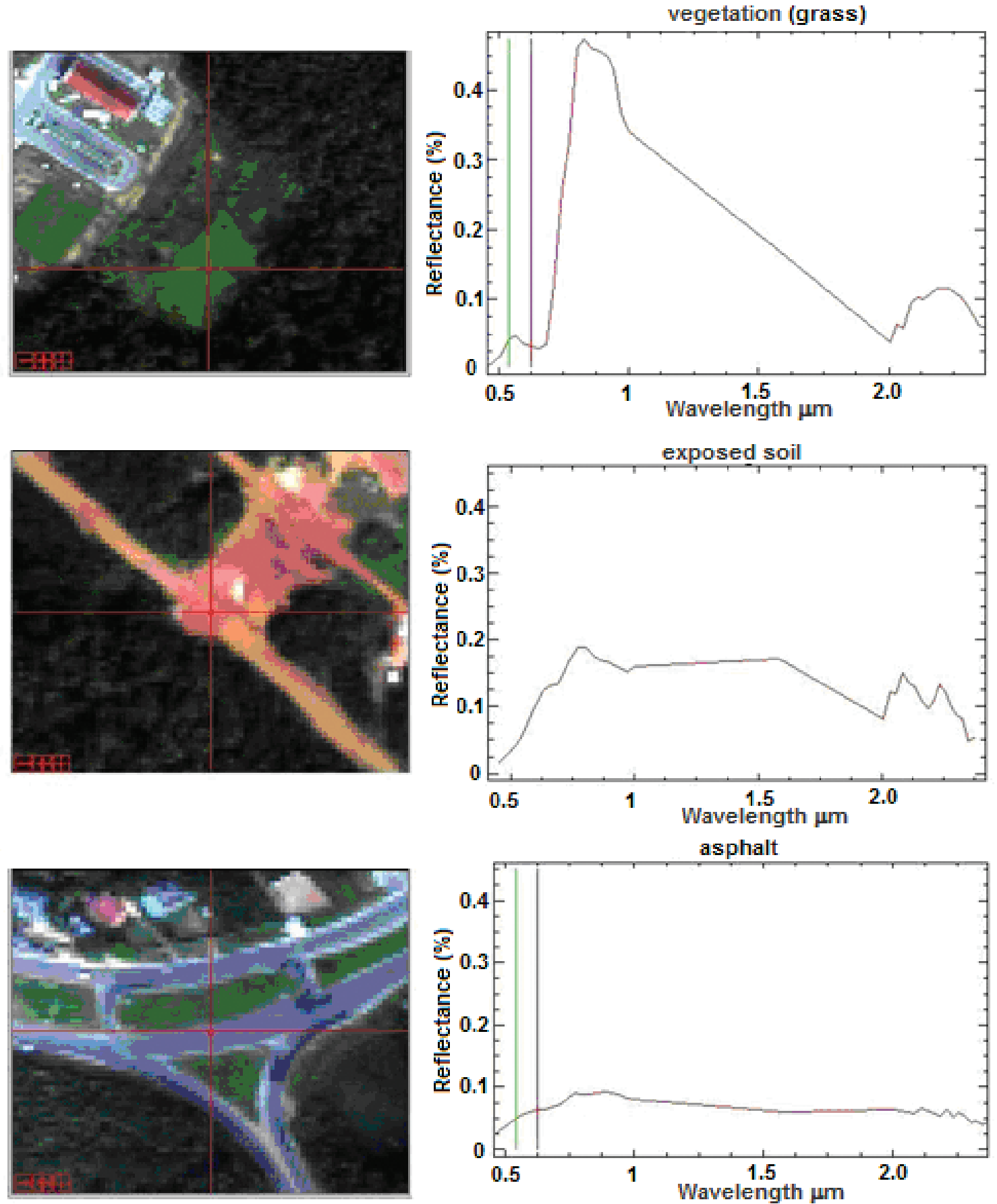

Figure 2 - Surface reflectance, spectra extracted from the HSS sensor image (value multiplied by $10^{4}$ ) after atmospheric correction processed by $F L A A S H$ and optimization with the EFFORT. R7G4B1 normal color compositions are shown for: vegetation, exposed soil and asphaltic pavement.

forms, shading, pattern and location. Besides the aforementioned elements, hyperspectral classifiers were applied - those that use average reference spectra obtained from the HSS own scene.

At Scene 1, out of the tested classifiers, SAM was the classifier with better results regarding the soil targets. This supervised classifier determines the similarity of a test spectrum for a reference spectrum. The SAM processing was accomplished for all targets at once, considering the mean angle generated from the endmembers in the interest area previously selected (soil reference spectra in the images). 


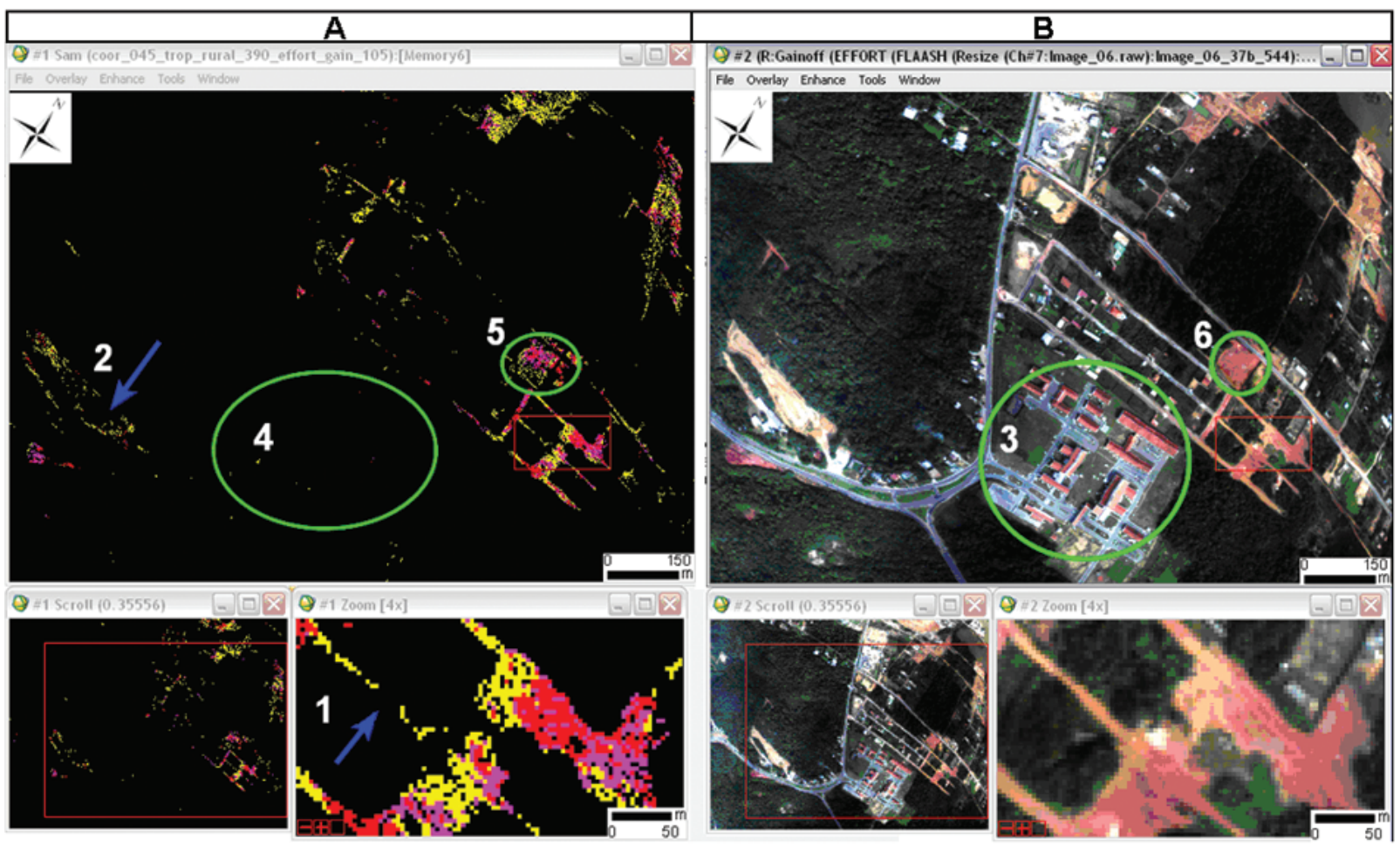

Figure 3 - Area near to SIPAM. A: SAM image and B: HSS's R7G4B1 composition. An intense contamination by adjacent pixels may be seen (blue arrow 1 and Green circles 5 and 6); anisotropic effect (arrow 2); and good separateness among the objects with materials similar to soils, mainly tiles of argilliferous composition (circles 3 and 4).

With the intention of obtaining a better classification, the option was for monitoring the angles in the rule images (SAM resulting image), being later divided into values and presented in colors.

In Scene 1, that includes the SIPAM area, three average spectra of soil samples taken from the image were used. The soil samples were appropriately identified in the SAM image, with 0.1 radian angles, as can be seen in the example given in Figure 3, where the SAM's image scene (to the left) is presented at the side of the HSS's R7G4B1 composition (to the right).

In the SAM image, a good definition was verified among the mapped classes (Fig. 3A), with the respective targets selected in the reflectance image (Fig. 3B). The soil ${ }^{1}$ targets selected in the reflectance image were yellow Latosol with reddish shades, classified within the red color in the SAM image; reddish colored Latosol with concretions of iron nodules, classified within the magenta color in the SAM image; and yellow Latosol, classified within the yellow color in the SAM image.

The classification did not contemplate some classes, however, later a punctual analysis was accomplished, where a strong influence of adjacent pixels was verified. This influence occurs due to the fact that those soils are situated in a small area, some 8 meter-wide streets, in other words, involving only about three pixels (blue arrow 1, in Fig. 3A).

Other non mapped soils are found in the Scene's border, where a visible anisotropy effect (blue arrow 2, in Fig. $3 \mathrm{~A}$ ) is seen, caused by the illumination and sight geometry - the relative position of the sensor towards the Sun - evidenced by the Sun's light retrospreading effect.

However, other objects made of material similar to soils, mainly tiles of argilliferous composition, were appropriately differentiated from the soils, as it can be verified observing the roof pixels of the SIPAM complex with argilliferous tiles (green circle 3, Fig. 3B), they did not present mapped classes in the SAM image (green circle 4, Fig. 3A), while in circle 6 such material is well-separated (Fig. 3B).

With the appropriate slicing, discriminated in colors, the good soil separateness was verified in relation to other targets; however, some patches of exposed soils were not mapped, evidencing spectral variation caused by frequent modifications (green circle,

\footnotetext{
${ }^{1}$ In the area, the pedologic unit consists, practically of yellowish Latosols (RADAMBRASIL, 1978). However, laterite exposures (plinthite horizons) and fillings are found in the mapped sites.
} 


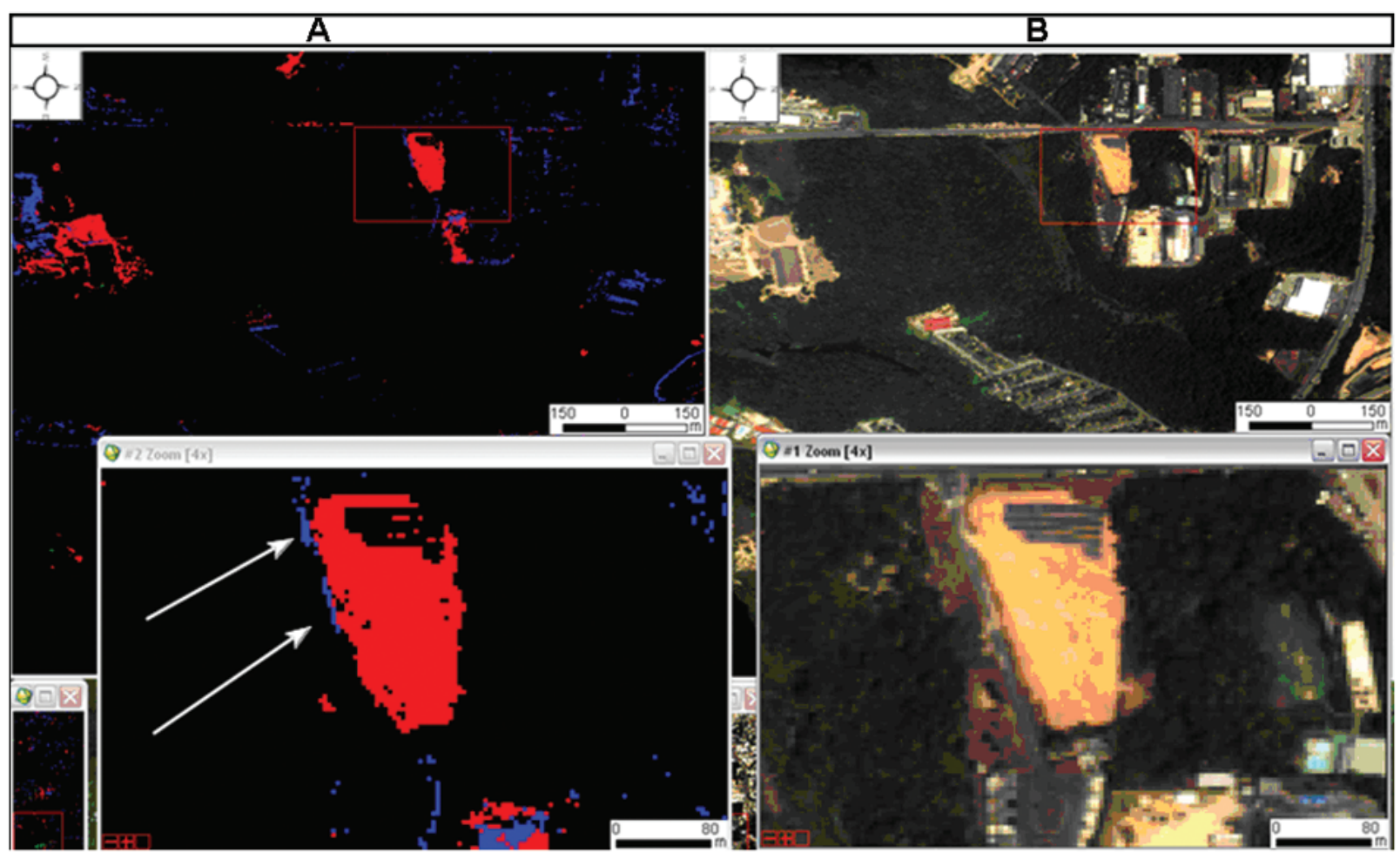

Figure 4 -A: SAM image (left) and B: HSS's R7G4B1 composition (right).

Fig. 3A), presented at the side of the HSS's R7G4B1 composition (green circle 6, Fig. 3B).

In the green circle 5 of Figure 3A, three classes of soils are noticed. Subsequent field evaluations demonstrated that this area underwent intense modifications, mainly due to the horizons excavation, used for building purposes.

Figures 4, 5 and 6 show Scene 2. Three average reference spectra were used for this classification, making possible, also, a preseparation of targets on soil.

In the SAM image of Figure 4, a good definition among the red class (Fig. 4A) is seen, soils presenting a redder color (Fig. $4 B$ ); in this case 0.08 radian was used. Some blue classes (white arrows, Fig. 4A), mapped with 0.065 radians, they appeared adjacent to the main area, but spectral analyses revealed that these classes occurred due to their sandier texture ${ }^{2}$ and not for spectral mixture of other targets.

Even in relation to the asphaltic pavement (white arrows, Fig. $4 A$ ), there was not spectral divergence. Field analyses revealed that these pavements are covered with soils from adjacent areas.

In the SAM image of Figure 5, there is a mixture of the blue with the red class. In this case there is a mixture of sandy with argillaceous materials. But in spite of the good discrimination in relation to soils of different textures, some divergence was verified in relation to pixels located in streets, asphalted avenues and constructions (green arrows, Fig. 5), possibly associated to asphalt spectra and aged constructions, with some amount of sand.

In Figure 6 the yellow soil (red arrow, Fig. 6B) was easily separated from the other targets in the SAM image, with angle of 0.08 radians, without discrepancies in relation to the adjacent soils. This soil, even presenting a very whitish color, was not mixed up with the blue class (sandy texture), a spectral separation being evidenced and it was not attributed to color.

Using the HSS images, previously classified by SAM, four areas were defined in the two classified scenes, where thirteen soil samples were collected (Table 1).

The identified soil ${ }^{3}$ classes/horizons/materials were: YelIow Latosols/plinthite horizon Bw2 (LP); Yellow Latosols/yellow horizon/sandy-clay Bw1 (LA); Yellow Latosols/horizon C (red) Alter do Chão Formation (LV); Sandy-Quartz Neosoils/sandy material (NQ).

\footnotetext{
${ }^{2}$ Texture refers to the clay, silt and soil proportion in the soil.

${ }^{3}$ In order to deal with the soils in the remote sensing area, the concept of geologic or physic soil will be adopted, corresponding to what is denominated as "weathered rock" (Guerra \& Guerra, 2009). It also includes fragments from artificial deposits of any type of material removed by men, and such places are called fillings.
} 


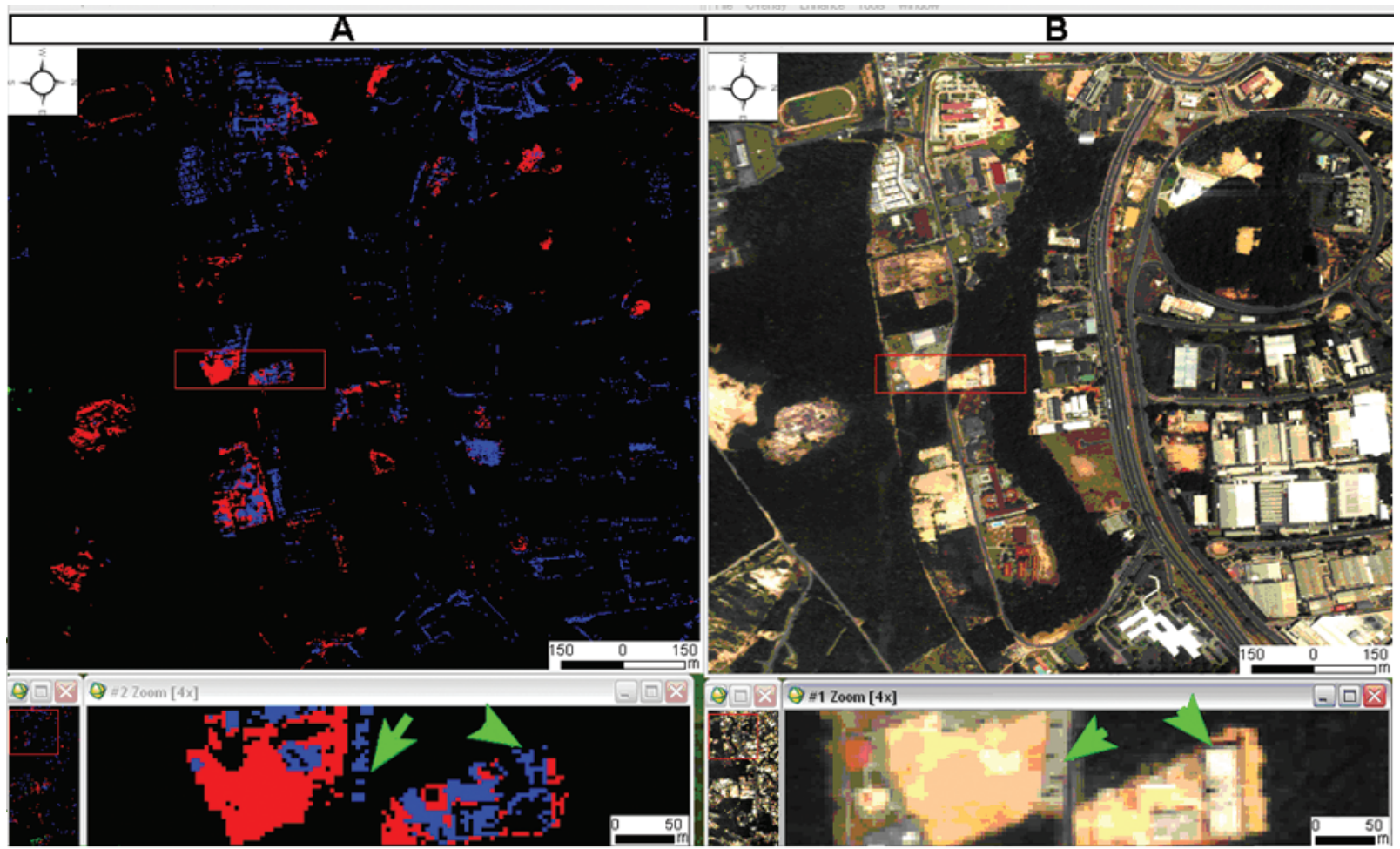

Figure 5 - A: SAM image (left) and B: HSS's R7G4B1 composition (right).

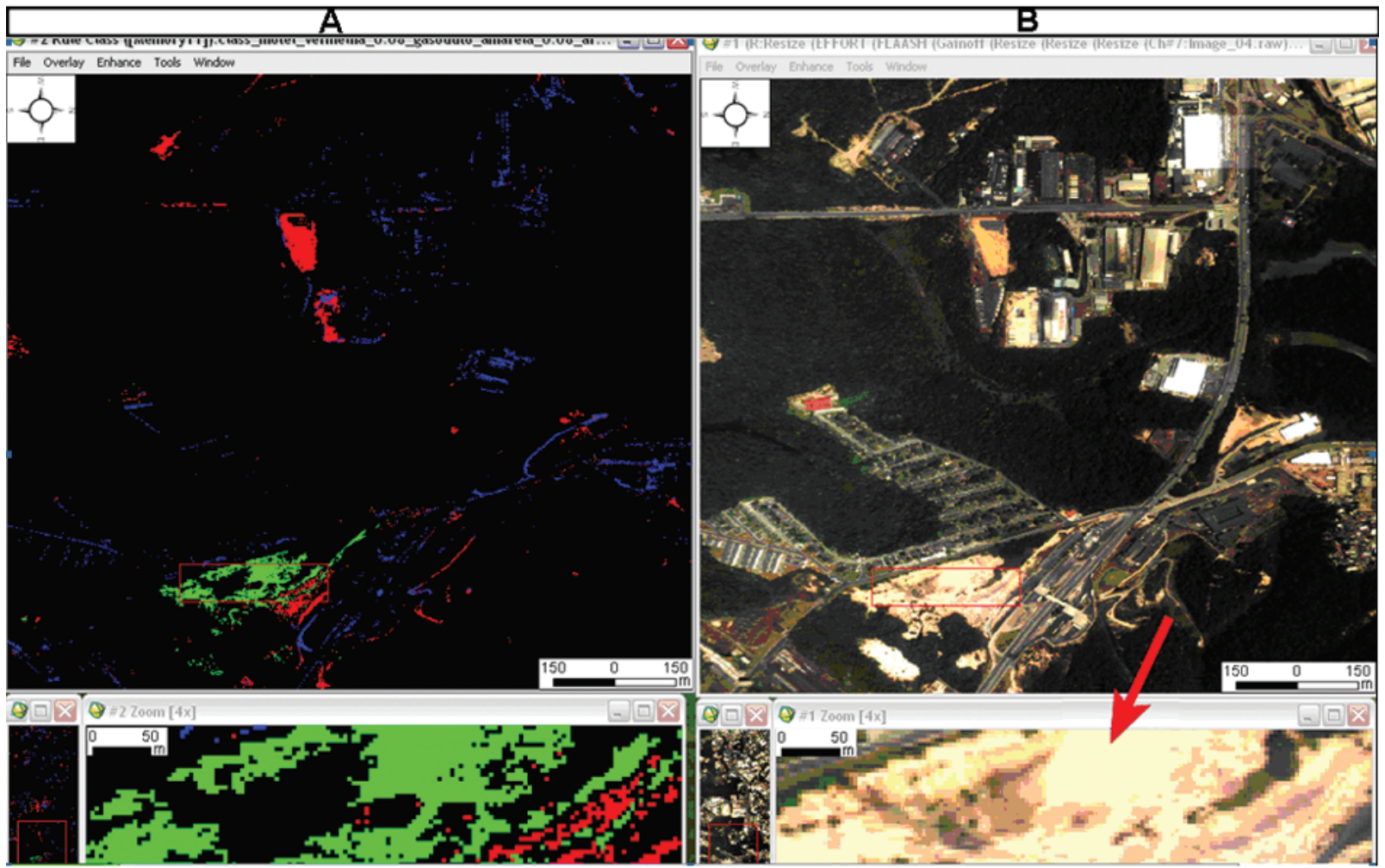

Figure 6 - A: SAM image (left) and B: HSS's R7G4B1 composition (right) 
Table 1 - Sample identification, class/horizon/material, granulometry, textural classification, organic matter and iron.

\begin{tabular}{|c|c|c|c|c|c|c|c|}
\hline $\begin{array}{c}\text { Sample } \\
\text { identification }\end{array}$ & Class / Horizon / Material & Sand & Silt & Clay & $\begin{array}{c}\text { Textural } \\
\text { classification }\end{array}$ & $\begin{array}{c}\text { Organic matter } \\
(\mathrm{g} / \mathrm{kg})\end{array}$ & $\begin{array}{c}\mathrm{Fe} \\
\left(\mathrm{mg} / \mathrm{dm}^{3}\right)\end{array}$ \\
\hline A1 LP & $\begin{array}{c}\text { Yellow Latosol / Bw2 Plinthite Horizon / } \\
\text { Ferruginous Profiles }\end{array}$ & 25.976 & 7.574 & 66.45 & Very Clayey & 5.39 & 27 \\
\hline A2 LP & $\begin{array}{l}\text { Yellow Latosol / Concretions of } \\
\text { Iron Nodules (Laterite) }\end{array}$ & 24.245 & 11.705 & 64.05 & Very Clayey & 4.22 & 8 \\
\hline A3 LA & Yellow Latosol / Bw1 Yellowish Horizon & 15.233 & 6.817 & 77.95 & Very Clayey & 3.5 & 2 \\
\hline A4 LP & $\begin{array}{c}\text { Yellow Latosol / Bw2 Plinthite Horizon / } \\
\text { Ferruginous Profiles }\end{array}$ & 37.093 & 12.107 & 50.8 & Clay & 2.2 & 19 \\
\hline A5 LP & $\begin{array}{c}\text { Yellow Latosol / Bw1 Yellowish Horizon / } \\
\text { Ferruginous Profiles }\end{array}$ & 12.522 & 9.078 & 78.4 & Very Clayey & 10.05 & 66 \\
\hline A6 LP & $\begin{array}{c}\text { Yellow Latosol / Bw2 Plinthite Horizon / } \\
\text { Ferruginous Profiles }\end{array}$ & 28.698 & 15.652 & 55.65 & Clay & 8.2 & 13 \\
\hline $\mathrm{A} 7 \mathrm{NQ}$ & Neosols (Arenite Material) & 97.648 & 0.852 & 1.5 & Sand & 2.75 & 38 \\
\hline A8 LA & Yellow Latosol / Bw1 Yellowish Horizon & 56.762 & 14.738 & 28.5 & $\begin{array}{l}\text { Franco Sandy } \\
\text { Argillaceous }\end{array}$ & 2.2 & 1 \\
\hline A9 LV & $\begin{array}{l}\text { Yellow Latosol / Horizon C (Reddish) } \\
\text { of the Alter do Chão Formation }\end{array}$ & 24.708 & 13.492 & 61.8 & Very Clayey & 2.54 & 2 \\
\hline $\mathrm{A} 10 \mathrm{NQ}$ & Neosols (Arenite Material) & 99.166 & 0.234 & 0.6 & Sand & 0.39 & 20 \\
\hline A11 LA & Yellow Latosol / Bw1 Yellowish Horizon & 64.615 & 3.535 & 31.85 & $\begin{array}{l}\text { Franco Sandy } \\
\text { Argillaceous }\end{array}$ & 2.44 & 11 \\
\hline A12 LV & $\begin{array}{l}\text { Yellow Latosol / Horizon C (Reddish) } \\
\text { of the Alter do Chão Formation }\end{array}$ & 72.926 & 3.724 & 23.35 & $\begin{array}{l}\text { Franco Sandy } \\
\text { Argillaceous }\end{array}$ & 1.27 & 7 \\
\hline A13 LP & $\begin{array}{c}\text { Yellow Latosol / Bw1 Yellowish Horizon / } \\
\text { Ferruginous Profiles }\end{array}$ & 66.269 & 4.181 & 29.55 & $\begin{array}{l}\text { Franco Sandy } \\
\text { Argillaceous }\end{array}$ & 4.01 & 27 \\
\hline
\end{tabular}

\section{Correlations among soil characteristics and the sensor's (HSS) spectral data and spectral curves at the laboratory (FRB)}

\section{Relationships among physicochemical constituents}

It is appropriate to evaluate the soil physicochemical constituents' relationships amongst themselves, before verifying their influence on the spectral signature of the studied samples. Table 2 shows the correlation matrix among the physicochemical constituents of thirteen analyzed soil samples, and all correlation coefficients are significant at $5 \%$. As the samples' content of total sand increases, the total clay and organic matter contents are reduced. The best correlations were between total sand and total clay $(r=-0.9901)$, total sand and silt $(r=-0.7089)$.

The high negative correlation between total sand and the other chemical and physical constituents shows that the bigger the sand fraction, the smaller the organic matter, silt fraction and, espe- cially, the total clay fraction of the constituents' content, that presented the best result $(r=-0.9901)$.

There was not a correlation between iron and the other constituents, since the same soil type prevail in both environments. For the iron case, there is a difference because at Scene 1 there exists a great amount of concretions of iron nodules or laterite, which are also evidenced in the spectral analyses.

Table 2 - Results for correlation among the physicochemical constituents of 13 soil samples.

\begin{tabular}{|c|c|c|c|c|}
\hline & Argila total & Fe & Silt & Total sand \\
\hline Total Clay & & & & \\
Fe & 0.0488 & & & \\
Silt & 0.6035 & -0.2801 & & \\
Total Sand & -0.9901 & 0.0058 & -0.7089 & \\
0.M. (g/kg) & 0.6342 & 0.5898 & 0.3926 & -0.6297 \\
\hline
\end{tabular}




\section{Attributes of the soil versus terrestrial reflectance (Fieldspec) and the (HSS) sensor}

The behavior or spectral signature, both at the laboratory or at the terrestrial level, depends directly on its chemical, physical, biological and mineralogical composition (Table 1). Soils present different constituents, which can be identified through the analysis of their spectral responses.

The spectral signature is the result of the interaction of the electromagnetic radiation with the soil attributes, such as: parental material, organic matter, iron oxides, mineralogy, granuIometry, humidity and surface rugosity. The results of the spectral analysis carried out by the FieldSpec will be presented considering the interval from 0.45 to $2.37 \mu \mathrm{m}$. The results obtained by the HSS sensor are presented in two wavelength intervals: from 0.45 to $1,0 \mu \mathrm{m}$, visible and near infrared, and from 2.0 to $2.37 \mu \mathrm{m}$, short wave infrared. These curves present typical features or absorption bands, due to the interaction of the atoms or molecules from different soil constituents with the electromagnetic radiation in specific wavelengths.

According to Hunt (1980), the absorption bands are caused by electronic and vibrational processes.

In the electronic process, transitions among the energy levels of the atomic orbitals are responsible for the absorption features in the spectra. These processes are accentuated in the part of the spectrum between the visible and near infrared.

According to Clark (1999), in the vibrational process, a free molecule can rotate and translate. These movements are denominated reticular vibrations and they typically occur at very low levels of energy, approximately, above $2.0 \mu \mathrm{m}$, in the areas of the short wave infrared.

Since each soil presents different composition, the referring spectral curve will have different absorption bands. The soil spectra analyses may facilitate the identification of some components and of some of their physical characteristics.

According to Meneses \& Ferreira Júnior (2001), when discussing the influence of the soil constituent materials on reflectance, among the most important are the argillaceous minerals such as kaolinite and montmorillonite, the aluminum and iron oxides, minerals such as calcite, gibbsite, organic matter and water.

Goethite $(\mathrm{FeOOH})$ and hematite $\left(\mathrm{Fe}_{2} \mathrm{O}_{3}\right)$ are the most frequent iron oxides in soils. These iron oxides show different spectral features in the ultraviolet regions, visible and near infrared (Fig. 7).

Basically, LP present strong features of energy absorption due to the higher iron grades than LA, NQ and LV (Table 1). This is ratified by the descriptive analysis of the form and absorption intensity (Figs. 7 and 8).
The spectral feature around $0.9 \mu \mathrm{m}$ with concave format indicates the presence of iron oxide, as well as the albedo reduction in relation to $L V, N Q$ and $L A$, evidenced in Figures 7 and 8. Spectral values found in Vitorello \& Galvão (1996) study show the concave format of the spectral curve in the $0.85 \mu \mathrm{m}$ band, also an indicative of iron.

According to Novo (2008), the decreasing gradient in the interval from 0.75 to $1.3 \mu \mathrm{m}$ is typical of soils with high iron oxide content.

In Figure 9, the spectra of Sample 8 are representative of soils lacking iron oxides and have as a characteristic the absence of an intense and wide band centered at $0.9 \mu \mathrm{m}$. As exposed by Meneses \& Ferreira Júnior (2001), iron oxide-rich soils exhibit the following characteristic features: one band centered at $0.65 \mu \mathrm{m}$, a wide band centered at $0.95 \mu \mathrm{m}$ and other between 0.45 and $0.53 \mu \mathrm{m}$.

The average spectral curves of the soil samples with higher clay contents resulted in less reflectance intensity, both by the ground and aerial sensors. For Sample 12 (Fig. 10) case, lesser reflectance intensity occurs due to high clay values not due to iron or organic matter present; both constituents also favor less reflectance.

LP show low reflectance between 0.1 and 02 , not presenting an escalating tendency along the spectrum (Fig. 11). These values are close to values obtained by Epiphanio et al. (1992), as for Purple Latosol with high iron grades.

The granulometry and presence of different argillaceous minerals have influence on their spectral answer (Madeira Netto, 2001). In addition, soils with a sandy texture tend to show a higher reflectance intensity than the argillaceous soils, especially when sand is made up of quartz (Fig. 12).

Samples A10 and A7, regarding Neosols (sandstone-like material), are by definition soils with a sandy texture, with low organic matter content, with sand-sized mineralogy made up predominantly of quartz, resulting in a high reflectance intensity all over the studied spectrum band (Fig. 12) and shallower depth in the absorption band of the argillaceous minerals, near $2.2 \mu \mathrm{m}$ (Fig. 13).

According to Simmons (1972) apud Batista (2006), the explanation for that behavior is attributable to the fact that the finest materials present a flatter surface, with less porosity to capture the incident light. In the field, reflectance on nondisturbed soils tend to show inverse results to those obtained at the laboratory. Reflectance of the argillaceous soils usually is inferior to reflectance from sandy soils. The explanation is that the structure of soils with a finer texture under nondisturbed 

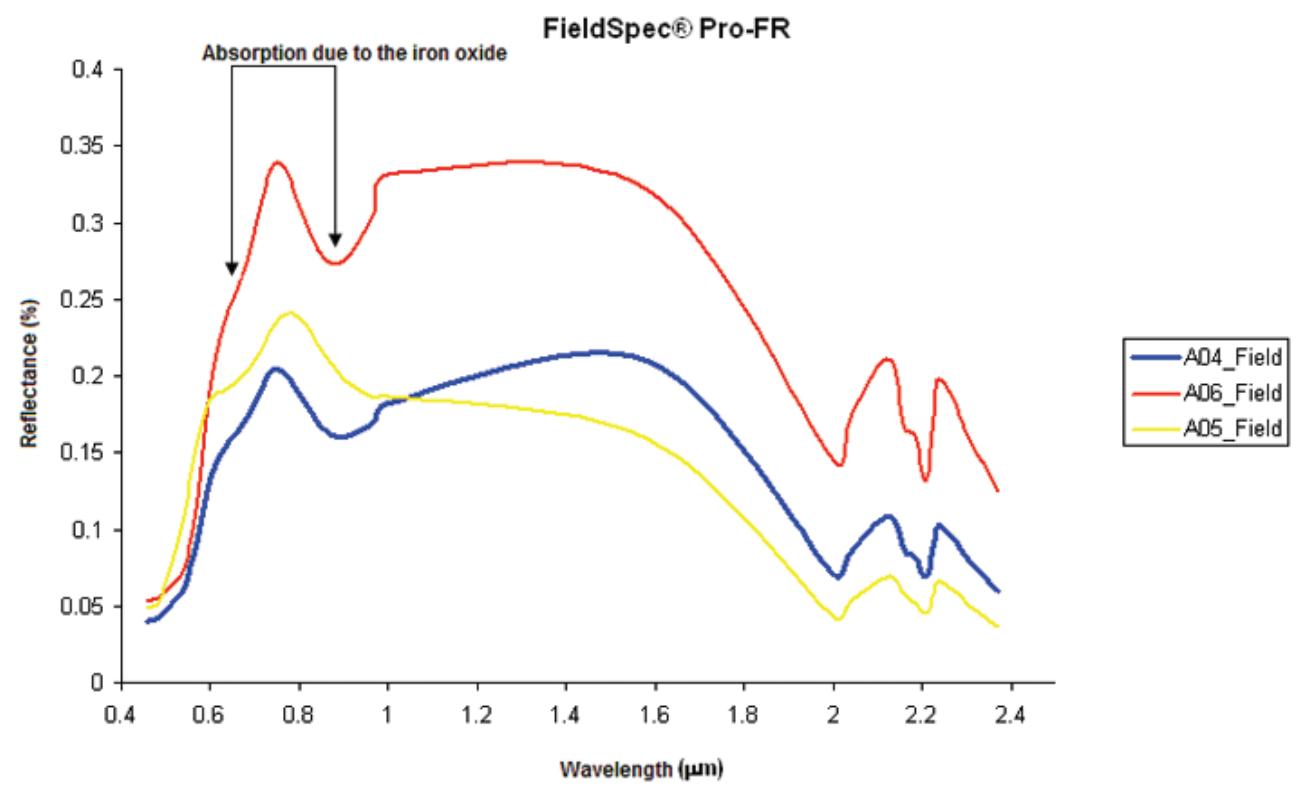

Figure 7 - Reflectance spectra of iron-containing samples in the FieldSpec sensor.

HSS

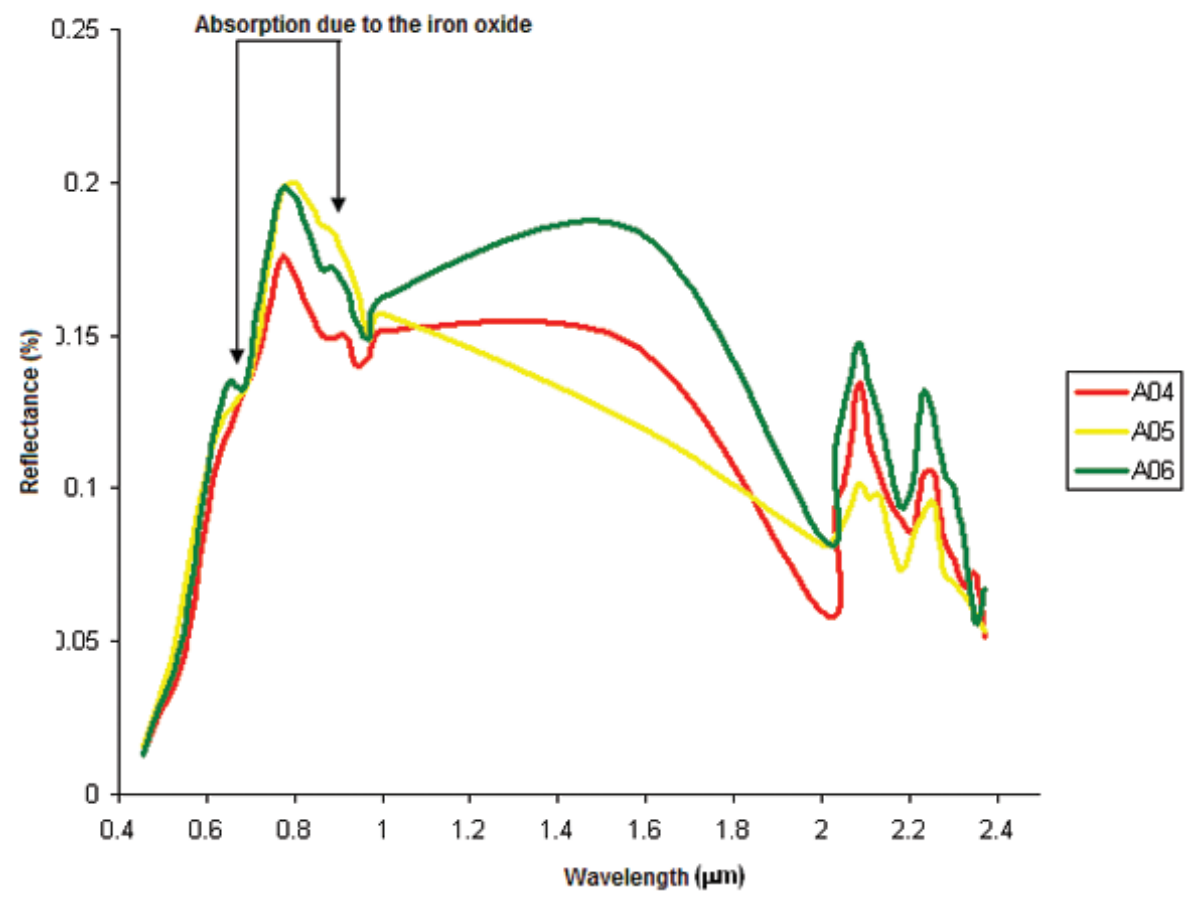

Figure 8 - Reflectance spectra of iron-containing samples in the HSS sensor.

conditions usually form bigger aggregates than sand (Myers \& Allen, 1968). This behavior was found in both sensors, in other words, there was an increase of the soil reflectance intensity from 0.45 to $2.37 \mu \mathrm{m}$, as the sand content increased and clay content decreased (Fig. 14).
In the spectral band from 0.7 to $1.0 \mu \mathrm{m}$, it may be seen that LP and LA had average to strong concavities, passing to weak or even null convexities in NQ.

Comparing the Latosols, it may be seen that LA is very similar to LP, differing basically in the iron content; the LA tended 
FieldSpec $($ Pro-FR e HSS
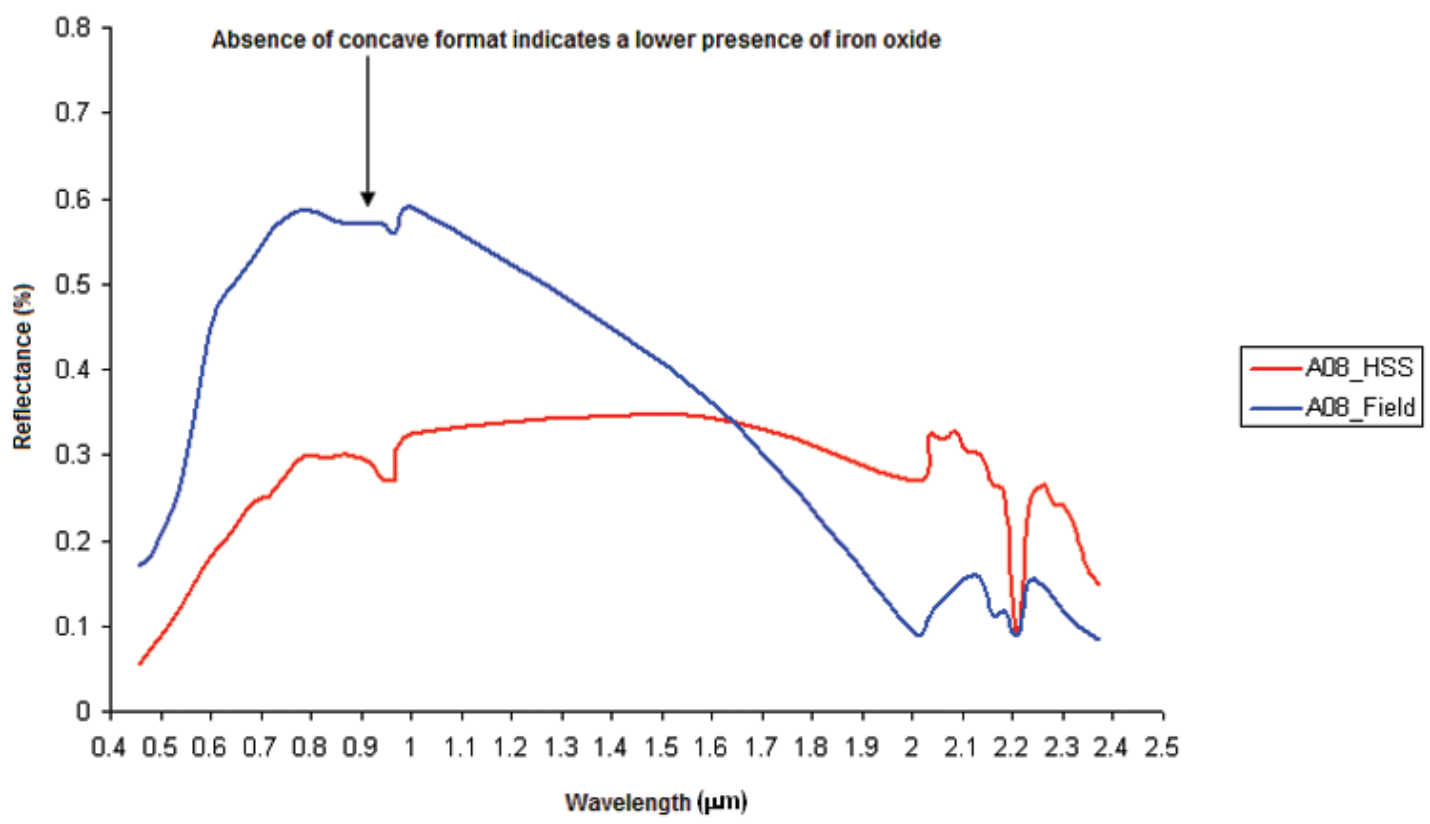

Figure 9 - The reflectance spectra of Sample 8, with insignificant iron oxide content.

FieldSpec ${ }^{\circledR}$ Pro-FR e HSS

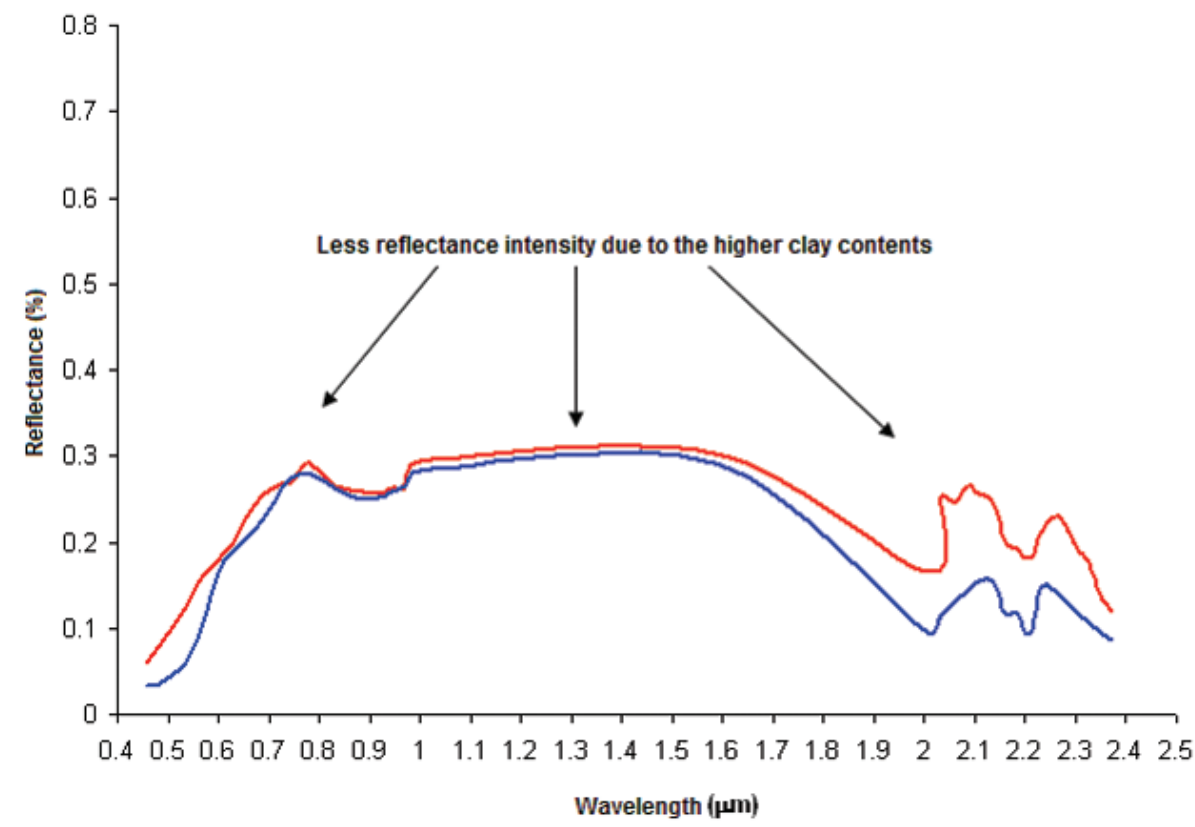

Figure 10 - Spectra of Sample 12, less reflectance intensity occurs due to high Clay values.

to present more intense reflectance, and the LP were disposed to absorb a larger amount of energy at ground and aerial levels. Differences among the Latosols' iron contents are distributed by the studied area, in other words, the highest iron grades are con- centrated in area 1, what can also significantly influence the low intensity of their reflectances, what means that the LP are under the influence of the exposed plinthite horizon, with laterite nodules present, with ferruginous profiles. 


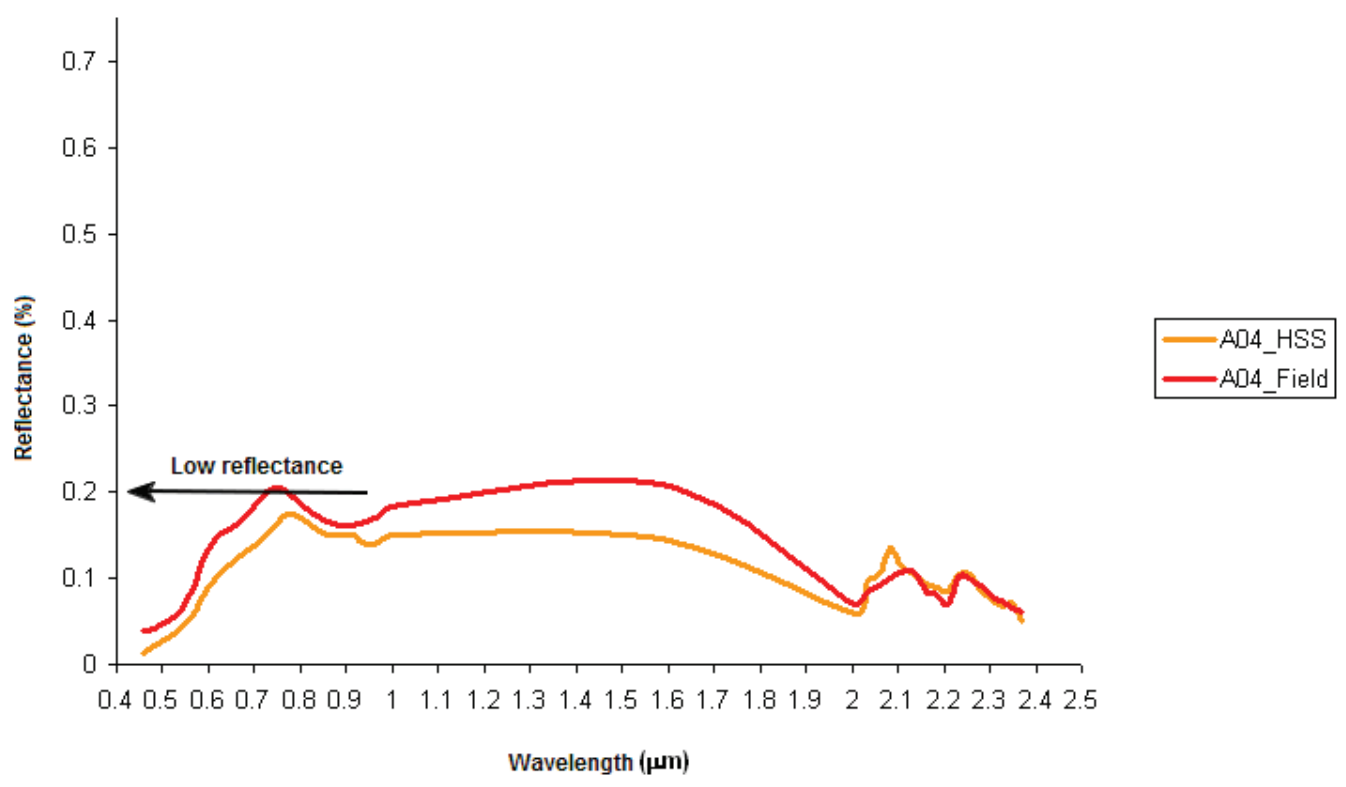

Figure 11 - The LP's reflectance spectra.

FieldSpec(8) Pro-FR e HSS

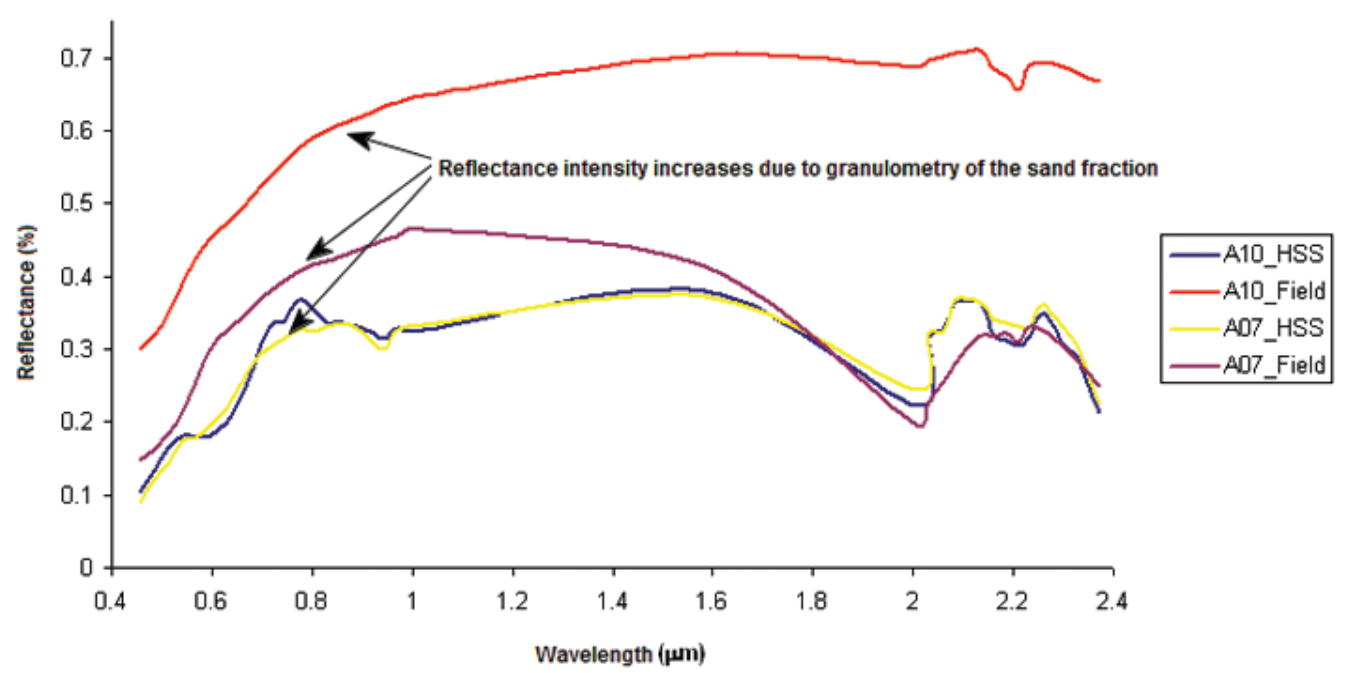

Figure 12 - Reflectance spectra of samples A10 and A7.

Therefore, Latosols are similar in the two studied areas, their main differences are the iron grades.

The soil's organic matter (M.O.) content is quite reduced when compared to the mineral content. However, its influence in the soil properties and, consequently, in the reflectance intensity is extremely important, because it is a color primary constituent, presenting a close relationship with the soil reflectance.

According to Moreira (2005), in sandy soils of desertic areas the organic matter reaches $0.5 \%$ of the total weight. In most of the cultivated soils, the organic matter content varies from 2 to $5 \%$ and, in some cases, it can reach $10 \%$.

For the analyzed samples, the organic matter content practically did not vary, from $2 \mathrm{~g} / \mathrm{kg}^{-1}$ to $10 \mathrm{~g} / \mathrm{kg}^{-1}$, in other words, values smaller than $1 \%$ of the total weight. Therefore, the effect of the iron feature stood out in relation to the organic matter.

Galvão \& Vitorello (1998) affirmed that the organic matter is the main component responsible for reflectance reduction in the 0.6 to $0.75 \mu \mathrm{m}$ band and, if more than $1.7 \%$ of M.0. is present, 
FieldSpec ${ }^{\circledR}$ Pro-FR e HSS

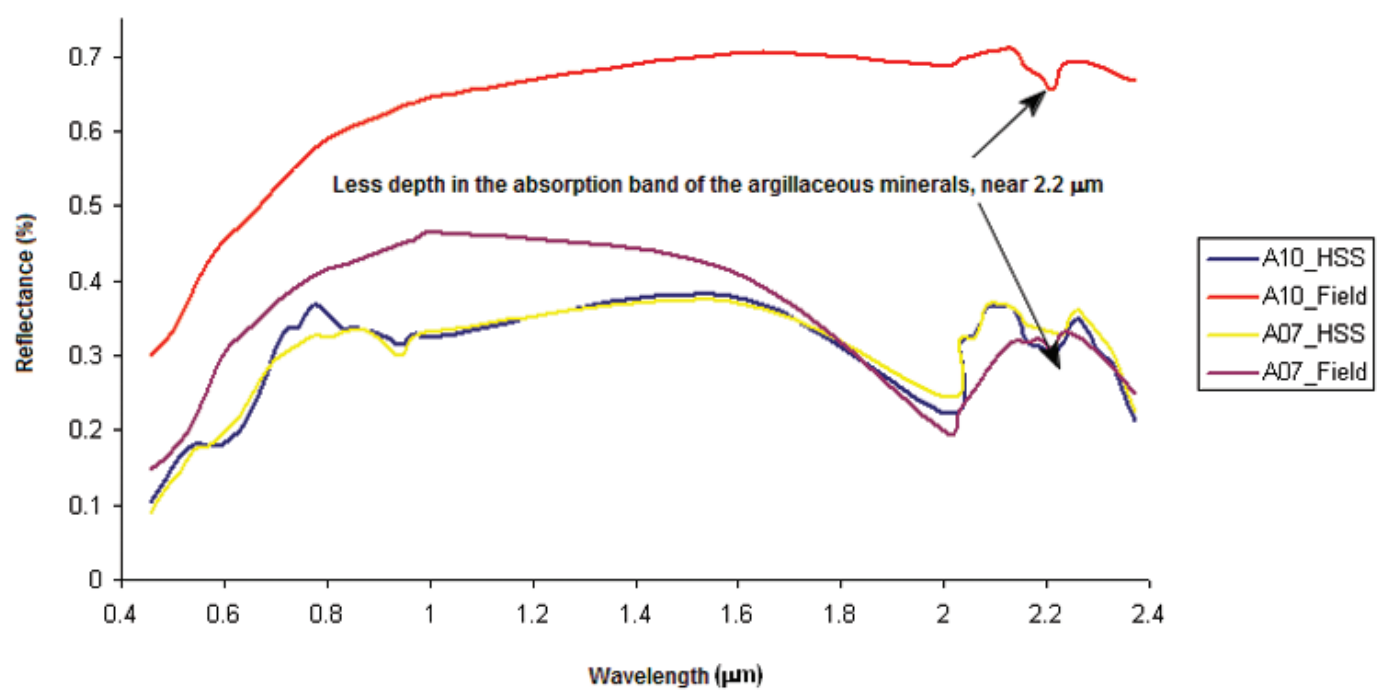

Figure 13 - Samples A10 and A7, referring to Neosols.

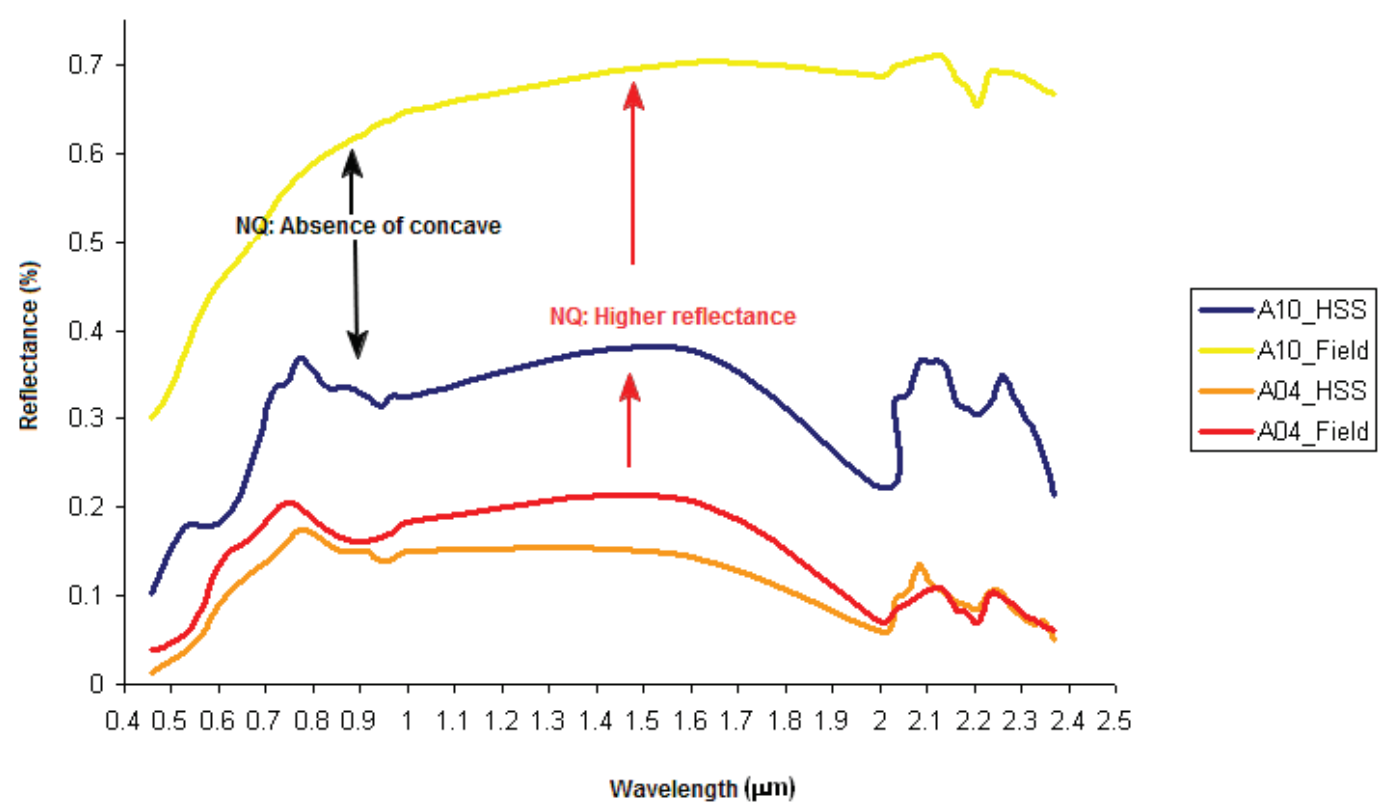

Figure 14 - Reflectance spectra of samples A10 and A04.

it would obliterate the iron spectral characteristics, inducing a reduction larger than $40 \%$ in the correlation between the total content of $\mathrm{Fe}_{2} \mathrm{O}_{3}$ and the reflectance.

In the case of this work, in every analyzed sample, low M.0. values - less than $1.0 \%$ - were observed (Table 1). When the M.0. content is below $2.0 \%$, other soil constituents, such as iron oxides, also observed in this work, become more influential in the soil's spectral behavior than the organic matter.
Baumgardmer et al. (1970) apud Moreira (2005) verified that, when the organic matter content in the soil exceeds $2.0 \%$, it plays an important role for determining the soil's spectral properties.

Opaque minerals, especially the iron oxides (goethite and hematite), tend to exert less influence on the reflectance intensity.

The sandy samples' albedo or with low iron oxide content tend to show lighter shades and more intense reflectance in the curves, especially in samples 7, 8, 9, 10, 11 and 12 . 


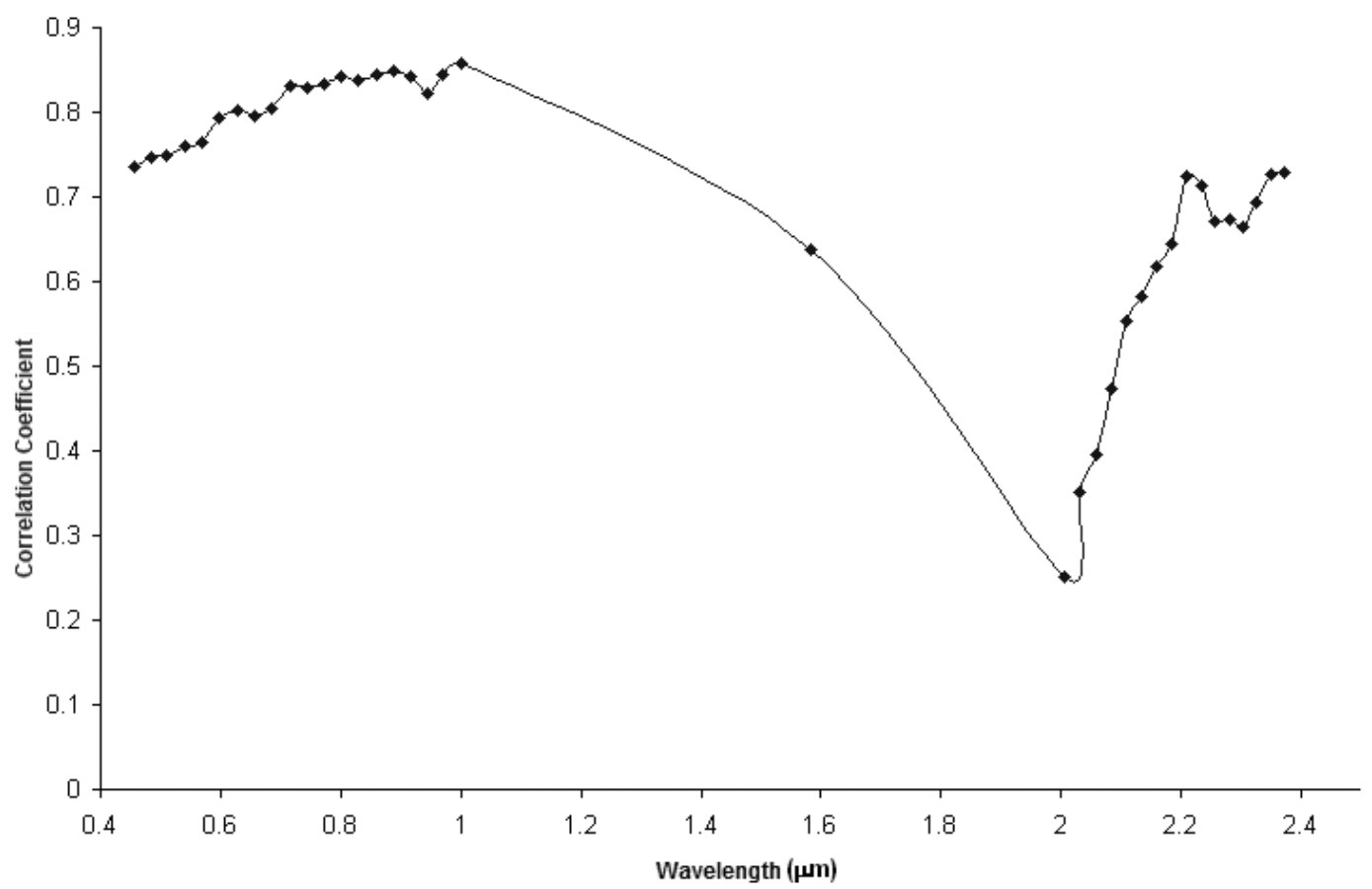

Figure 15 - Correlation coefficient among the reflectance values measured with the HSS and the Fieldspec for 37 wavelengths.

For samples 4, 5 and 6 's case, the result was the opposite, that is, the albedo and reflectance intensity showed low values since they present high clay fraction and iron oxide content.

\section{Correlation among the HSS (Sensor) Spectral and Fieldspec (Laboratory) Data}

Figure 15 displays the linear correlation coefficient ${ }^{4}$ among reflectances obtained through the HSS (aircraft) and FieldSpec (laboratory) for eight sampling sites. In this stage, correlations were calculated for 37 wavelengths; the spectroradiometer's band widths were convoluted using the spectral response from the HSS sensor. There is a better correlation in the 0.6 to $1.0 \mu \mathrm{m}$ interval, and poorer correlation in the 2.0 to $2.19 \mu \mathrm{m}$ interval. The poorer correlation was expected, since, at the atmospheric correction moment a subcorrection, among the HSS's 20 to 25 channels was evidenced. According to Moreira (2008), subsequent tests indicated that adjustments to the lesser in the parameter then identifies the $\mathrm{CO}_{2}$ concentration, close to $230 \mathrm{ppm}$, brought up benefits for the spectral continuity in the $2000 \mathrm{~nm}$ area, however, as a consequence, resulted in a low restitution of the $\mathrm{CO}_{2}$ influence.

However, according to Moreira (2008), it should be taken into consideration that for the C02 concentration, as for the water vapor, a reasonable variability along such a heterogeneous scene may occur, such as the urban area, with areas requiring more or less correction adjustments being expected.

It should be emphasized that, in spite of the magnitude differences of the HSS and FieldSpec's reflectance, spectra will grow towards the channels with longer wavelengths; a good proximity was verified in the field and imaged spectral profiles.

An important aspect to be pointed out when analyzing data is the correlation coefficients found among the HSS and FieldSpec's curves, in this case, not for wavelength, but for individual samples.

When carrying out individual analyses, linear regressions were accomplished among the spectra of both sensors, in this case, values obtained at the laboratory were adopted as independent variable and those from the HSS as dependent variable, shown in Figure 16.

Results from eight analyzed samples (Fig. 16) showed high correlations, with adjustments $(r=0.94),(r=0.91),(r=0.87)$; and smaller correlations ( $r=0.63),(r=0.65),(r=0.75)$.

Adoption of individual correlations made possible the identification of a better correlation among the samples; the same did not happen with correlations calculated for the thirty seven wavelengths, mainly, in the short wave Infrared (SWIR) band. How-

\footnotetext{
${ }^{4}$ All correlation coefficients are significant at $5 \%$.
} 

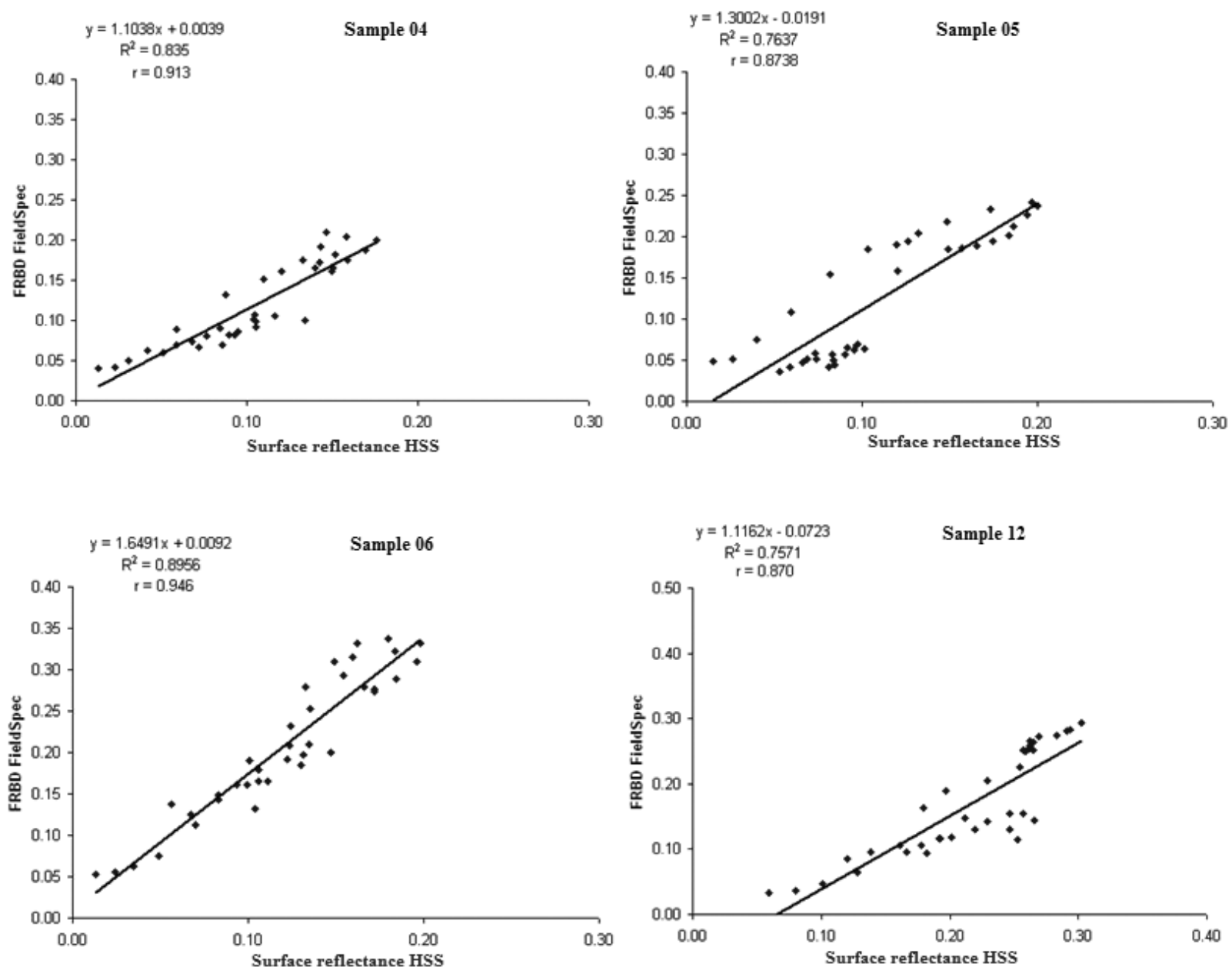

Figure 16 - Correlation coefficient calculated for individual samples.

ever, this variation that was seen is not only produced by the low $\mathrm{CO}_{2}$ restitution; in some spectra, it may be observed that curves have the same spectral behavior, however they present different absolute values.

This supposed variation is associated with the presence of more significant neighboring targets, in the image spectrum, than in the laboratory spectrum. These neighboring targets result in a smaller absolute value in the image. Baptista (2006) also observed this variation through the AVIRIS sensor's data.

\section{CONCLUSIONS}

a) Regarding preprocessing and the HSS sensor radiometric correction, the conclusion may be that:

Practically, the same parameters described by Moreira (2008) were used to obtain a better atmospheric correction. However, the main differences found were for the correction of water vapor, $\mathrm{CO}_{2}$ concentration, and the non deviation of approximately $0,017 \mu \mathrm{m}$ in the HSS sensor spectral calibration in channels 18 and 19, near to the water vapor absorption region of $0.94 \mu \mathrm{m}$;

The atmospheric correction undertaken with the FLAASH applicative was considered appropriate, in spite of the difficulties for full removal of the water vapor feature at $0.94 \mu \mathrm{m}$ and in the short wave infrared band, near to $2.0 \mu \mathrm{m}$;

No appropriate results were obtained with the pixel-topixel of the water vapor and aerosols corrections with the ratios of WR (Water Retrieval) and K-T (Kauffman-Tanré) bands.

In general, coherence of the HSS sensor's spectra with the information from the literature and the spectra obtained at the laboratory was verified; 
b) With respect to the preidentification of the soil classes in the images through the SAM classifier, it may be concluded that:

There is a good capacity of spectral identification with the SAM classifier, whose results made possible the appropriate preidentification of the soil classes, as well as the contribution for defining sites where field samples were collected;

Soil samples were appropriately identified in the SAM image, with angles smaller than 0.1 radians.

Some soils were not mapped due to the strong influence of the illumination geometry because of the HSS sensor wide field sight ( $\left.86^{\circ} \mathrm{FOV}\right)$, mainly at the edges of the image.

The use of the SAM classifier, with different angular values, including every imaged scene, facilitated not just the soil identification with the other targets, but also separation of visually similar soils.

Results demonstrated that the HSS images can contribute for discriminating the soil classes.

c) Regarding the correlations among the laboratory (FRB) and aircraft (HSS) data, and those with the physicochemical and mineralogical analyses, it may be concluded that:

LPs present strong energy absorption features due to the higher iron content than $L A, N Q$ and $L V$. This is ratified by the descriptive analysis of the absorption form and intensity of the curves in both sensors;

The mean spectral curves of the soil samples with higher clay content resulted in lower reflectance intensity, both from ground and aerial sensors;

LPs present low reflectance between 0.1 and 0.2 , without a tendency to increase along the spectrum;

Samples related with the Neosols (sandy material), presented high reflectance intensity in every band of the studied spectrum;

The organic matter content in the analyzed samples practically did not vary, from $2 \mathrm{~g} / \mathrm{kg}^{-1}$ to $10 \mathrm{~g} / \mathrm{kg}^{-1}$, in other words, values bellow $1 \%$ of the total weight. Thus, the effect of the iron feature stood out in relation to organic matter;

The albedo of the sandy samples, or with low grades of iron oxides, tend to end up with lighter shades and a more intense reflectance in the curves;
The spectral curves representative of the $L P, L A, N Q$ and LV soil classes, for the laboratory (FRB) and aircraft (HSS) data are correlatable;

Correlations between the two data acquisition environments (laboratory and HSS) are usually high, especially in the near infrared band. The lowest correlation coefficients were found in the spectral interval corresponding to the upper limit of the short wave infrared, above $2.0 \mu \mathrm{m}$.

Results, as a whole, demonstrated the potential of the imaging spectroscopy (hyperspectral remote sensing), specifically using the HSS sensor, for spectral characterization (spectra forms and mineral absorption bands), propitiating discrimination of the different classes of tropical soils and identification, in the spectra, of some of their mineral components.

\section{REFERENCES}

BAPTISTA GMM. 2006. Sensoriamento remoto hiperespectral: 0 novo paradigma nos estudos de solos tropicais. Brasília, Universa, 212 p.

CLARK RN. 1999. Spectroscopy of rocks and minerals, and principles of spectroscopy. In: RENCZ AN (Ed.). Manual of remote sensing - vol. 3 Remote sensing for the earth science. John Wiley and Sons, Nova York.

EMBRAPA. 2006. Sistema brasileiro de classificação de solos / [editores técnicos, Humberto Gonçalves dos Santos et al.] - 2 ed. - Rio de Janeiro: Embrapa solos, p. 306.

EPIPHANIO JCN, FORMAGGIO AR, VALERIAN MM \& OLIVEIRA JB. 1992. Comportamento espectral de solos do Estado de São Paulo. São José dos Campos: INPE, p. 132.

FERNANDES FILHO LA, COSTA ML \& COSTA JBS. 1997. Registros neotectônicos nos lateritos de Manaus - Amazonas. Geociências, 16(1): 9-33.

GALVÃO LS \& VITORELLO I. 1998. Role of organic matter in obliterating the effects of iron on color and on spectral reflectance of Brazilian tropical soils. Int. J. Remote Sensing, 1969-1979.

GUERRA AT \& GUERRA AJT. 2009. Novo dicionário geológico-geomorfológico - 7 Ed. Rio de Janeiro, 652 p.

HUNT GR. 1980. Electromagnetic radiation: the communication link in remote sensing. In: SIEGAL BS \& GILLESPIE AR. Remote sensing in geology. New York: J. Wiley \& Sons, p. 5-45.

KRUSE FA, LEFKOFF AB, BOARDMAN JB, HEIDEBRECHT KB, SHAPIRO AT, BARLOON PJ \& GOETZ AFH. 1993. The Spectral Image Processing System (SIPS) - Interactive Visualization and Analysis of Imaging spectrometer Data. Remote Sensing of the Environment, 44: 145-163.

LEAL PC. 1996. Caracterização e interpretações genéticas de alguns soIos da região de Manaus, AM. M.Sc. dissertation. UFPe. 109 p. 
MADEIRA NETTO JS. 2001. Comportamento espectral de solos. In: MENESES PR \& MADEIRA NETTO JS (Eds.). Sensoriamento remoto: reflectância dos alvos naturais, Brasília, UnB, Planaltina: Embrapa Cerrados, p. 127-154.

MELO MC, MENDES VL, MOREIRA RC \& CASTRO RM. 2009. Metodologia para obtenção de reflectância de alvos urbanos em laboratório. Anais XIV Simpósio Brasileiro de Sensoriamento Remoto, Natal, Brasil, INPE. 1143-1149p.

MENESES PR \& FERREIRA JÚNIOR LG. 2001. Comportamento espectral de minerais e rochas. In: MENESES PR \& MADEIRA NETTO JS (Eds.) Sensoriamento remoto: reflectância dos alvos naturais, Brasília, UnB, Planaltina: Embrapa Cerrados, p. 63-123.

MOREIRA MA. 2005. Fundamentos do sensoriamento remoto e metodologia de aplicação. Viçosa, $320 \mathrm{p}$.

MOREIRA RC, CASTRO RM, ESPÓSITO ESC \& LUCCA EVD. 2005. Sensor hiperespectral HSS: sumário das características técnicas. In: XII Simpósio Brasileiro de Sensoriamento Remoto, Goiânia, Anais, p. 45174524.
MOREIRA RC. 2008. Estudo espectral de alvos urbanos com imagens do sensor HSS (Hyperspectral Scanner System). Tese de doutorado - São José dos Campos: INPE, 237 p.

MYERS VI \& ALLEN WA. 1968. Electrooptical remote sensing methods as nondestructive testing and measuring techniques in agriculture. Applied Optics, Washington, DC, V.7, p. 1818-1838

NOVO EMLM. 2008. Sensoriamento remoto: princípios e aplicações. São Paulo, 388 p.

OLIVEIRA FM, ARAÚJO RLC, CARVALHO JS \& COSTA SS. 2008. Determinação da variação no microclima de Manaus-AM por atividades antropogênicas e modulações climáticas naturais. Acta Amazonica, 38(4): 687-700.

RESEARCH SYSTEMS INC. 2000. ENVI user's guide. Version 3.4. Lafayette: Better Solutions Consulting, p. 614.

VITORELLO I \& GALVÃO LS. 1996. Spectral proprieties of geologic material in the 400 to $2500 \mathrm{~nm}$ range: review for applications to mineral exploration and lithologic mapping. Photo Interp., p. 77-99.

\section{NOTES ABOUT THE AUTHORS}

Manoel Ricardo Dourado Correia. Geography doctorate student at Universidade Federal de Santa Catarina, UFSC, M.Sc. in Geosciences (Universidade Federal do Amazonas, 2009), Specialist in Geoprocessing (Faculdade de Goiás, 2006), MBA in Sanitary and Environmental Engineering (IPOG, 2011), B.Sc. in Geography (Universidade Federal de Goiás, 2005). Analyst of the Remote Sensing Division of the Sistema de Proteção da Amazônia - SIPAM (2006-2010). Currently teaches at Centro Universitário do Norte (UniNorte/Laureate), works as a public officer at the Geology Municipal Office (Directory of Analysis and Cartography of Natural Risks).

Rutenio Luiz Castro de Araújo. D.Sc. in Geophysics (Universidade Federal do Pará, 1987), M.Sc. in Geophysics (Universidade de São Paulo, 1977), B.Sc. in Physics (Universidade Federal do Rio de Janeiro, 1973). Currently is an effective professor in the Geosciences Department of the Universidade Federal do Amazonas, works as teacher and researcher since 1980. Works in the Applied Geophysics field, mainly with Environmental Geophysics. 